\title{
Temporal assessment of the medicinal plants trade in public markets of the state of Paraíba, northeastern Brazil
}

\author{
Ezequiel da Costa Ferreira ${ }^{1,2^{*}}$, Reinado Farias Paiva de Lucena ${ }^{2,3}$, Rainer W. Bussmann ${ }^{4}$, \\ Narel Y. Paniagua-Zambrana ${ }^{4}$ and Denise Dias da Cruz ${ }^{1,2^{*}}$ (D)
}

\begin{abstract}
Background: Open and public markets are the main providers of medicinal plants in urban environments. The present study evaluated the medicinal plants sold in public markets in different municipalities in the mesoregions of the state of Paraíba, northeast of Brazil, and the possible variations in the supply of these plants in the markets over the course of a year.

Methods: Interviews with medicinal plant traders were conducted in four mesoregions of different climatic and phytophysiognomic characteristics (ranging from Caatinga to Atlantic Forest). The versatility of the species sold was elucidated using the relative importance (RI) index, and the set of species sold by each informant in each mesoregion was compared with each other by one-way Anosim and by the analysis of main coordinates.

Results: Thirty-five plant traders identified 163 medicinal plant species (151 genders and 76 families) and more 17 non identified species. The most frequent families were Fabaceae (19 species), Asteraceae (12), Lamiaceae (11), and Myrtaceae (6). Punica granatum, Zingiber officinale, and Myracrodruon urundeuva were the species with the highest Rl. The analysis of similarity showed distinct differences between the Sertão and all other mesoregions. The Agreste, an ecotone area, was also the area where more species of other regions was found. The absence of 88 species in at least one of the trading locations at some stage of the fieldwork was recorded.
\end{abstract}

Conclusions: The presence and absence of the commercialized species do not seem to be related to the period of the year or the mesoregion. There were differences in the inventory of plants commercialized in markets in recent years. We identified an intermediate zone of knowledge and use of species commercialized between the studied localities.

Keywords: Urban ethnobotany, Caatinga, Atlantic Forest, Similarity analysis, Relative importance

\section{Background}

The knowledge about and use of medicinal plants are themes that remain one of the main study topics in ethnobotany. Many recent studies in Brazil and around the

\footnotetext{
*Correspondence: ezequielcostaf@gmail.com; denidcruz@dse.ufpb.br ${ }^{1}$ Laboratório de Ecologia Terrestre, Dept. de Sistemática E Ecologia, Centro de Ciências, Exatas e da Natureza, Universidade Federal da Paraíba, João Pessoa, PB 58051-900, Brazil

Full list of author information is available at the end of the article
}

globe have recorded the knowledge and use of medicinal plants, in both rural [e.g., 1-8] and urban areas [e.g., 9-15].

In urban areas, open air and public markets are some of the main sources of medicinal plants. There it is possible to find these products traded and to observe variations with regard to both the plant parts sold and the inventory of available species over time. Several studies observed a predominance of the medicinal use of non-permanent original author(s) and the source, provide a link to the Creative Commons licence, and indicate if changes were made. The images or other third party material in this article are included in the article's Creative Commons licence, unless indicated otherwise in a credit line to the material. If material is not included in the article's Creative Commons licence and your intended use is not permitted by statutory regulation or exceeds the permitted use, you will need to obtain permission directly from the copyright holder. To view a copy of this licence, visit http://creativecommons.org/licenses/by/4.0/. The Creative Commons Public Domain Dedication waiver (http://creativeco mmons.org/publicdomain/zero/1.0/) applies to the data made available in this article, unless otherwise stated in a credit line to the data. 
plant structures, such as leaves $[8,16,17]$. Some studies in Brazil showed that overall, changes in the list of traded species occurred as a function of the temporal availability or the demand for certain species in the market [10, 18-20]. In other cases, it was possible to observe a relatively constant inventory of medicinal plants, with the inclusion of some new species over time, e.g., in La Paz, Bolivia [21], in both the short and medium term [21]. When observing broader temporal contexts, the changes in the inventory of medicinal plants can become more evident, as observed in Peru, where the local pharmacopeia has been changing since the colonial period [22].

The climate and the predominant phytophysiognomy (the main plant physiognomy or vegetation cover in a region) in a given region can also influence the set of traded species or the plant parts used. From this perspective, the more ample use of permanent plant structures such as bark and roots has been often documented from drier areas, such as the Caatinga [23-25] (semiarid region of Brazil), as well as in Savannah and Desert areas in Africa [26-28]. In humid areas, it has been more common to observe a greater use of leaves, such as in the Atlantic Forest [29] and the Amazon [30], as well as in rainforest areas in Asia [17, 31, 32].

In addition to the availability of the specific plant parts used, several other factors can influence the availability of traded products, such as seasonality $[18,20]$, demand [18], and local environmental factors [33]. Repeated sampling can be useful to identify and understand these variations in the medicinal plant products available for trade $[10,33]$.

Variations in the availability of traded plants have also been observed when comparing different public markets, even in nearby areas [21] or in long-term comparisons with previous studies $[19,21]$. Another issue that can influence the trade and use of medicinal plants is globalization, especially due to the increase and use of social and digital media to advertise and trade these products [34], and the medicinal plant trade in the international context [13].

The present study aimed to assess the medicinal plants traded in the public markets of municipalities in four mesoregions of the state of Paraíba, northeastern Brazil, each with its independent climatic and phytophysiognomy characteristics, but with two well-defined biomes: the Caatinga semiarid region, and the Atlantic Forest humid region. The assessment was performed by documenting the species used and the possible variations in their availability in the markets throughout the year. We hypothesized that there would be a greater influence of seasonality on the availability of medicinal plants for trade in the interior of the state, a region with a semiarid climate, than in the coast, which is subject to higher humidity over the year, especially with respect to native species. The hypothesis assumes that in areas where rainfall is more uniformly distributed throughout the year, such as the coast, vegetative structures of the native flora also maintain certain uniformity throughout the year, such as perennial species that keep the leaves. So, the inventory of the plants is often higher and more parts of the plants can be found in the markets. On the other hand, in the interior of the state, characterized as a semiarid region, rainfall is seasonal and generally concentrated in specific periods of the year. In this region, deciduous plants are more common and structures such as the leaves can be shed during the dry season, and thus, other vegetative structures are used by the community. Thus, the interior of the state of Paraíba, with a semiarid climate, would have a more marked influence of seasonality on the use of plants.

\section{Materials and methods Study area}

The study was conducted in public markets of seven municipalities of Paraíba, distributed in the four mesoregions of the state: João Pessoa and Sapé (Mata mesoregion), Guarabira and Solânea (Agreste mesoregion), Monteiro (Borborema mesoregion), and Patos and Itaporanga (Sertão mesoregion). The predominant phytophysiognomy in the municipalities of João Pessoa and Sapé is Atlantic Forest, while Caatinga vegetation predominates in the remaining municipalities (Fig. 1). These mesoregions are defined by socioeconomic and environmental characteristics, showing marked climatic variations. In 2017, when our fieldwork was already in progress, the IBGE (Brazilian Institute of Geography and Statistics) changed the division of the geographic regions of Brazil, modifying the configuration and the classification as mesoregions and microregions into intermediate regions and immediate regions, respectively [35]. For this study, we adopted the mesoregion and microregion classification, because this classification allows better visualization of the different phytophysiognomies of the state, considering that the new Regional Division of Brazil is more focused on socioeconomic aspects [35], not highlighting the environmental differences.

The Mata Paraibana mesoregion is characterized by a hot and humid climate [36] with three climate types according to the classification by Köppen: Aw (tropical, with a dry season in winter), Am (high rainfall), and As (hot and humid tropical, with dry winter) [37]. The Mata Paraibana shelters what little is left of the Atlantic Forest in Paraíba, most which has been destroyed by anthropogenic impact, especially the expansion of sugarcane production. This zone also incorporates beaches, plateaus, floodplains, and estuaries [36]. 


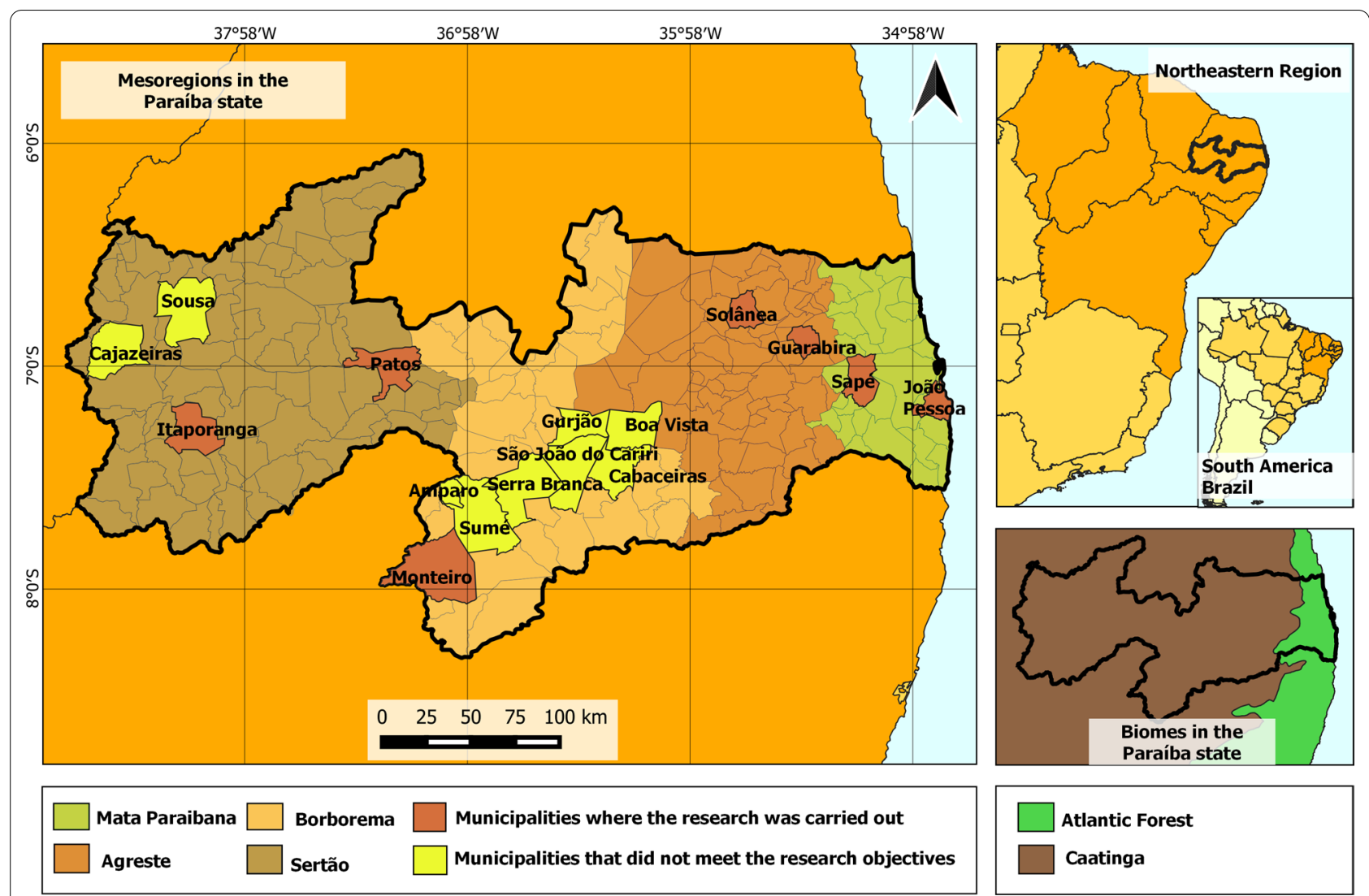

Fig. 1 Map of the state of Paraíba, Brazil, highlighting the studied municipalities, the municipalities where it was impossible to conduct the research, the four mesoregions of the state, and the predominance areas of the biomes

The Agreste comprises a transition area between the humid and the semiarid climate [36], belonging to the Köppen climate types As and Bsh (hot semiarid) [37]. Its vegetation represents also a transition area between the Atlantic Forest and the Caatinga [36].

The Borborema comprises the central area of the state of Paraíba, located in the geomorphological unit of the Borborema Plateau [36]. It shows the Köppen climate types As and Bsh [37], with the lowest rainfall levels in the state, and salty, thin, and rocky soils.

The Sertão comprises several depressions, with a semiarid climate, and a vegetation characteristic of the Caatinga [36]. This area is divided between the Köppen climate types Bsh (hot semiarid) and As (hot and humid tropical, with dry winter) [37].

Before beginning the interviews, previous visits were made to identify locations that met the objectives of the study. It was impossible to conduct the research in some of the visited municipalities (Fig. 1), either because they did not have a public market or because there were no medicinal plants traded in the market.

\section{Data collection}

Visits were made to the trading locations of medicinal plants in the public markets of the municipalities (Fig. 2). After initial contact to properly present and explain the purposes of the study, the medicinal plant traders in the markets were invited to sign the Free Consent Form (TCLE) required by the National Health Council through the Research Ethics Committee (Resolution 466/12) (Protocol: 82943618.0.0000.5188) and to participate in the research. In the countryside of the state, once a week the movement of commerce is intense and popularly known as "fair day." The interviews were conducted, preferably, on days with less movement in the markets, avoiding the "fair day," when traders have to pay more attention to their customers.

The free list technique was used based on the following question: "Which medicinal plants do you sell?" Subsequently, for each plant, details on their origin (was a plant from the local vegetation? did it come from other regions? was it imported?), considering both native and exotic species, and registering their applications, 


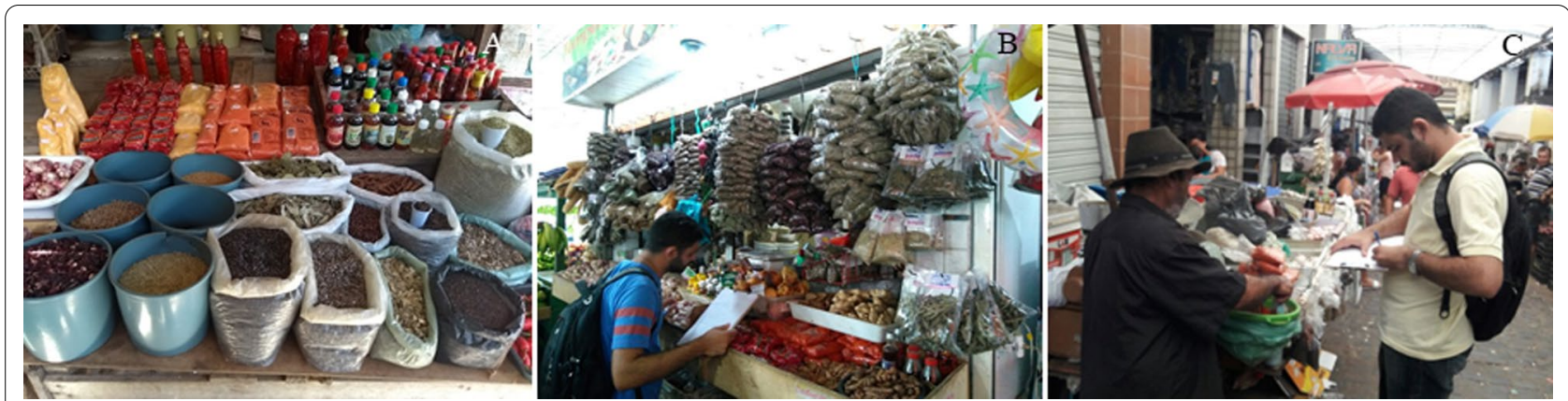

Fig. 2 Posts of medicinal plants in public markets of Paraíba state, northeast of Brazil. A Central market, João Pessoa; B Mangabeira market, João Pessoa; $\mathbf{C}$ public market, Guarabira

properties, preparation, parts used, and contraindications. In the context of this study, the stem was considered as both the shoot and its subterraneous structures (rhizome and bulb), when present. Repeat interviews were performed each trimester during one year (from August 2017 to July 2018), in order to evaluate if a species was either absent or added in relation to the previous periods. During each interview, a list of all plants available in a specific trade location was compiled, and further details were obtained on the use of each species.

The identification of the traded species was made by acquiring fertile specimens in the markets and collecting the cited species in the field when possible, and then comparing the material with the corresponding literature. At the end of each interview, samples of material were purchased from each trader, as a way of rewarding $\mathrm{him} / \mathrm{her}$ and strengthening the ties between researcher and interviewee. The names and families of the species were confirmed using REFLORA (Flora do Brasil 2020) [38] and the Missouri Botanical Garden database (Tropicos) [39]. The herborized plants were sent to the Herbarium Jaime Coelho de Moraes (EAN) of the Federal University of Paraíba (UFPB), Center of Agricultural Sciences (CCA), for confirmation of the identification and incorporation into the plant collection.

\section{Data analysis}

The therapeutic indications mentioned by the informants were classified according to body systems (categories defined by the WHO for each property) [40]. The BS (number of body systems) and PH (number of pharmacological properties) for each species were calculated according to Bennett and Prance [41], with the following equations:

$$
\mathrm{BS}=\mathrm{BSS} / \mathrm{BSVS}
$$

where BS refers to the number of body systems, resulting from the division of the number of body systems treated by a given species (BSS) by the total number of body systems treated by the most versatile species (BSVS), considering as the most versatile the species that obtained the greatest diversity of body systems.

The following equation was used for the $\mathrm{PH}$ :

$$
\mathrm{PH}=\mathrm{PHS} / \mathrm{PHVS}
$$

where NP is the number of properties, resulting from the division of the number of properties attributed to a given species (PHS) by the number of properties attributed to the most versatile species (PHVS), considering as the most versatile the species that obtained the highest number of properties.

Subsequently, also based on Bennett and Prance [41], the relative importance (RI) of each species was calculated by the following equation:

$$
\mathrm{RI}=\mathrm{BS}+\mathrm{PH} .
$$

This method highlights the most versatile species or those with the greatest diversity of uses. It consists of a quantitative method that is not directly influenced by the number of citations for a given species but rather by the diversity of applications inferred to a species. The maximum value obtained is 2 ; the closer to this value is the $\mathrm{RI}$ of the plant, the greater its versatility, also considering that the RI of the species is high when $\geq 1$.

The one-way ANOSIM permutation test was used to assess the degree of similarity of the species used between mesoregions (Bray-Curtis distance and 9999 permutations). This test produces an $\mathrm{R}$ result that ranges from -1 to +1 , which may indicate no significant difference between groups $(\mathrm{R}<0.25)$, while values between $0.25<\mathrm{R}<0.5$ indicate some data similarity and values of $\mathrm{R}>0.75$ indicate different results, with total difference when $\mathrm{R}=1$. Principal coordinates analysis (PCoA) using the Bray-Curtis distance was employed to generate a graph representing these differences between the cited species. The software Past 3.22 was used in the analyses. 
Data tabulation in the software was made based on the presence and absence of matrix in binary code, in which 1 represents the presence of the species considered in the trade location and 0 represents the absence.

\section{Results}

All medicinal plant traders found in the markets that agreed to participate in the survey were interviewed. Only two traders refused to participate ( 1 in Zona da Mata and 1 in Sertão). Traders who were not found at the tends throughout all the research period (one year and quarterly monitoring) were excluded from the sample: Two traders in the Agreste and one in the Sertão were excluded. A total of 35 traders were interviewed (13 in the Mata Paraibana; 10 in the Agreste; 4 in the Borborema; 8 in the Sertão). The age of the traders ranged between 23 and 81 years, and 54.3\% were men and $45.7 \%$ were women.

\section{Commercialized species, used category, and plant parts traded}

A total of 163 species were identified at least to genus level, belonging to 151 genera and 76 families. Seventeen species remained unidentified. The most common families were Fabaceae (19 species), Asteraceae (12), Lamiaceae (11), and Myrtaceae (6) (Table 1).

A high relative importance value was recorded $(\mathrm{RI} \geq 1)$ for 32 species, among which 11 were native to Brazil and 21 were exotic (Table 2). The species most often found in the markets were Foeniculum vulgare Mill. (erva doce; found in 35 posts, $\mathrm{IR}=1.59$ ), Pimpinella anisum $\mathrm{L}$. (erva doce; 34, 1.59), Peumus boldus Molina (boldo do Chile; 33, 1.13), Matricaria chamomilla L. (camomila; 31, 1.17), all exotic species. The species that obtained the highest RI values were Punica granatum L. (romã ; RI=2), Zingiber officinale Roscoe (gengibre; 1.78), and Myracrodruon urundeuva Allemão (aroeira; 1.69) (Tables 1 and 2). Despite the high RI value observed, these species were registered in less than a half of the trade points, except $Z$. officinale which occurred in 23 points.

The categories with the highest number of citations for each mesoregion were: unspecified diseases and symptoms; digestive system; endocrine system, nutrition, and metabolism; and respiratory system, with varying prevalence according to each mesoregion (Fig. 3). On the other hand, there was a variation in the categories with low number of citation among the mesoregions. Sensory system was more cited in the Borborema mesoregion than in others mesoregions. (In Agreste, this category was not cited by the interviewers.) Skin and subcutaneous tissue were less observed in the Borborema and, however, were frequent in the others mesoregions (Fig. 3).
The plant parts traded most commonly for medicinal use were leaves, bark, and seeds, varying only with regard to their prevalence in each mesoregion (Fig. 4). The use of flowers stood out in the Borborema region (Fig. 4). The use of the bark predominates in the Agreste mesoregion, while leaves were the most traded plant structure in the remaining mesoregions. The bark commercialization also varied among the mesoregions; it was more common in the Zona da Mata and Borborema than in the Agreste and Sertão.

\section{Similarity between the mesoregions}

Among the recorded species, 27 ( $16.1 \%$ of the total) were found only in the Mata mesoregion. However, the Sertão showed the highest exclusivity, with 45 species $(26.8 \%)$. The Agreste mesoregion had only four exclusive species (2.4\%), while the Borborema mesoregion had only three exclusive species (1.8\%) (Table 1). The one-way ANOSIM multivariate analysis demonstrated similarity among the set of species traded in the mesoregions, with exception for the Sertão, which was significantly different from all other mesoregions $(\mathrm{R}=0.2136 ; p<0.0018)$, showing significant variation compared to the Mata $(R=0.2632$; $p<0.0074)$, Agreste $(\mathrm{R}=0.3752 ; p<0.0036)$, and Borborema mesoregions $(\mathrm{R}=0.3888 ; p<0.0187)$. The principal coordinate analysis $(\mathrm{PCoA})$ highlighted the similarity between the plant species traded by the informants in three of the mesoregions compared to the Sertão (Fig. 5).

The four mesoregions shared 35 species. The oneway ANOSIM multivariate analysis demonstrated significant similarity between the mesoregions, except for the Sertão, which showed a significant difference from all remaining mesoregions. The difference between the Sertão and the remaining mesoregions could also be observed in the principal coordinates analysis (Fig. 5).

\section{Species presence and absence in the trade points}

During the study period, 88 species were unavailable at least once at least at one of the traders interviewed (Table 3). The Mata was the mesoregion where the highest number of species was absent at some point during the year, while the Borborema was the region with least seasonal absence of species.

Two species deserve special attention in this scenario: (1) Miconia albicans, which in the beginning of the study was registered in few trade points, however, increased the frequency throughout the year, and was registered in many trade points at the end of the study, and (2) $F$. vulgare, which was cited by the traders as a common local cultivated species, but it was not observed in some moments of the year and, in this period, it had higher prices. 

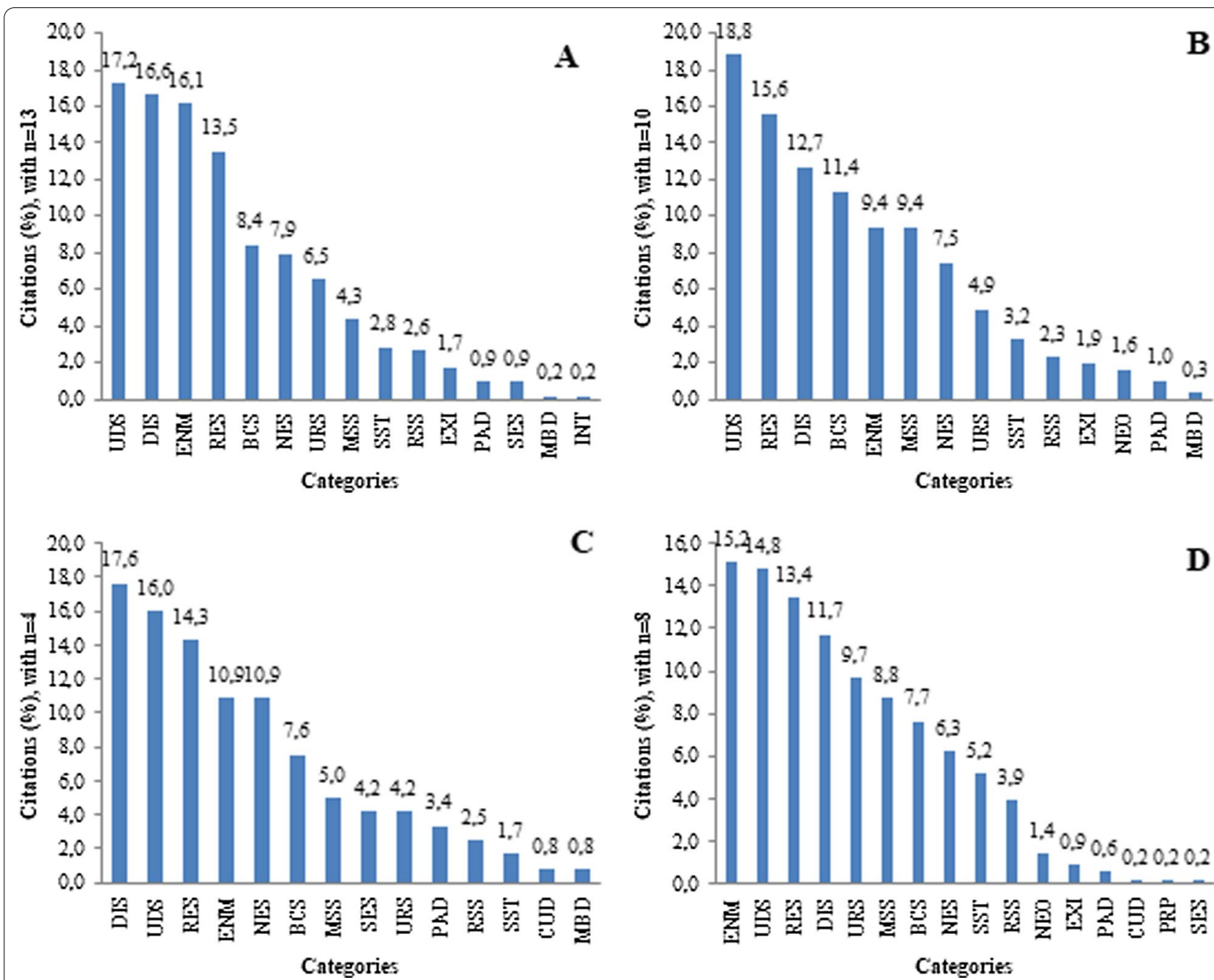

Fig. 3 Percentage of citations for each category of medicinal use in public markets of Paraíba, northeastern Brazil. $n=$ number of informants in the mesoregion. $\mathrm{BCS}=$ blood and cardiovascular system; $\mathrm{CUD}=$ cultural diseases; $\mathrm{DIS}=$ digestive system; $\mathrm{ENM}=$ endocrine system, nutrition, and metabolism; $\mathrm{EXI}=$ external injuries; $\mathrm{INT}=$ intoxication; $\mathrm{MBD}=$ mental and behavioral diseases; $\mathrm{MSS}=$ musculoskeletal system; $\mathrm{NEO}=$ neoplasms; $\mathrm{NES}=$ nervous system; $\mathrm{PAD}=$ parasitic diseases; $\mathrm{PRP}=$ pregnancy and parturition; $\mathrm{RES}=$ respiratory system; $\mathrm{RSS}=$ reproductive system and sexual health; SES = sensory system; SST = skin and subcutaneous tissue; UDS = unspecified diseases and symptoms; URS = urinary system. $\mathbf{A}$ Mata, $\mathbf{B}$ Agreste, C Borborema, D Sertão

\section{Discussion}

The medicinal plant species traded in the public markets of Paraíba were shared among the mesoregions, except for the Sertão, which had a more specific group of plants for sale. Climatic and seasonal variations did not seem to greatly influence plant availability throughout the year, considering that traders in general keep a stock of dry plants to ensure the supply of most species.

\section{Local knowledge and the medicinal plant trade}

The highest relative importance values were recorded for Punica granatum, Zingiber officinale, and Myracrodruon urundeuva. Although these species were recorded in all studied mesoregions and kept a relatively frequent availability in the trading locations during the research, previous studies involving some of the studied municipalities did not record these species in the market. In Guarabira, P. granatum was not previously recorded among the main species, and $Z$. officinale and $M$. urundeuva were also not recorded in a previous study conducted in the market of Patos [24], even though M. urundeuva occurs naturally in the region $[42,43]$. These data may indicate that over the past decade changes have occurred in plant availability or in the local importance of medicinal plants traded in these markets. It is worth mentioning that these species 


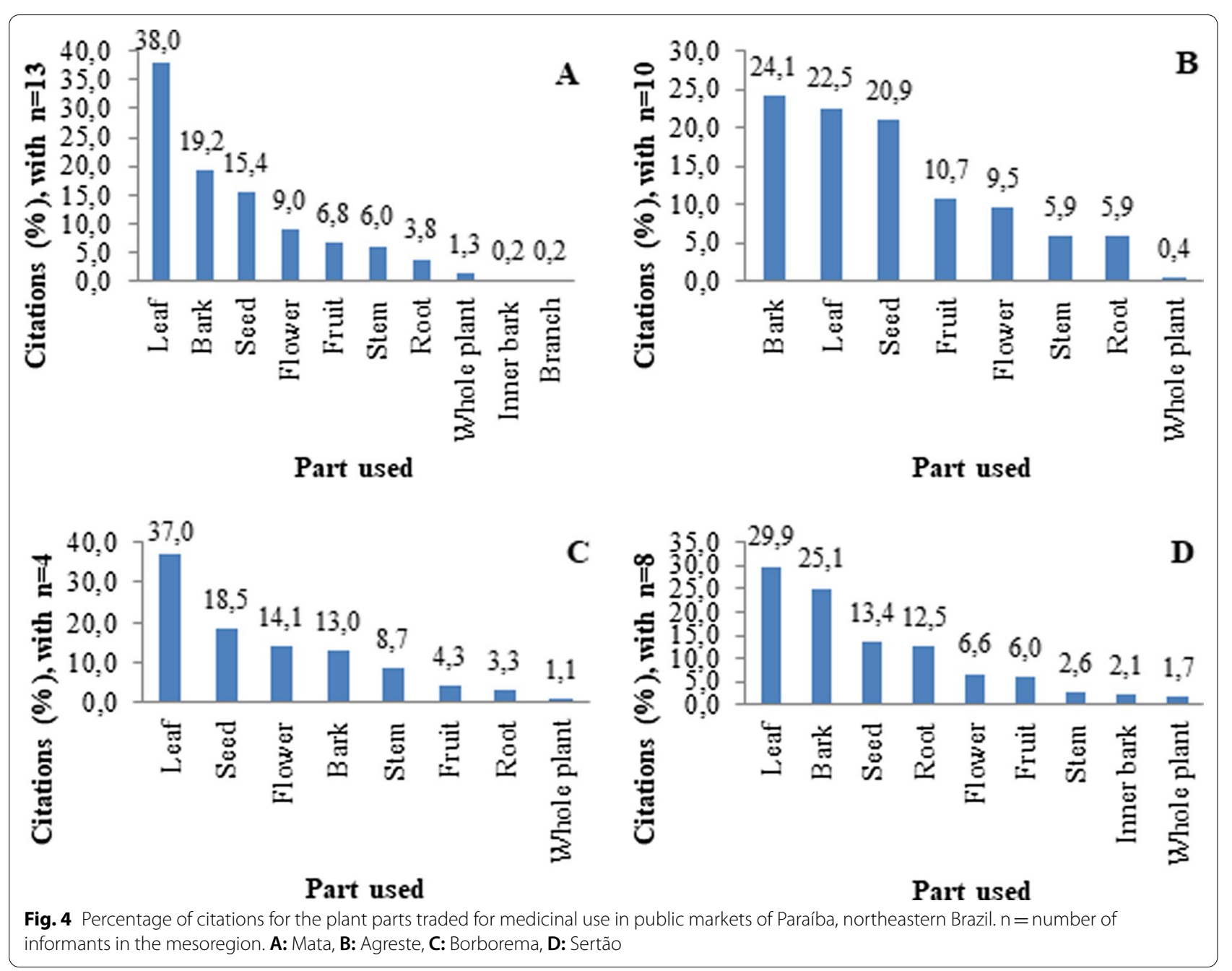

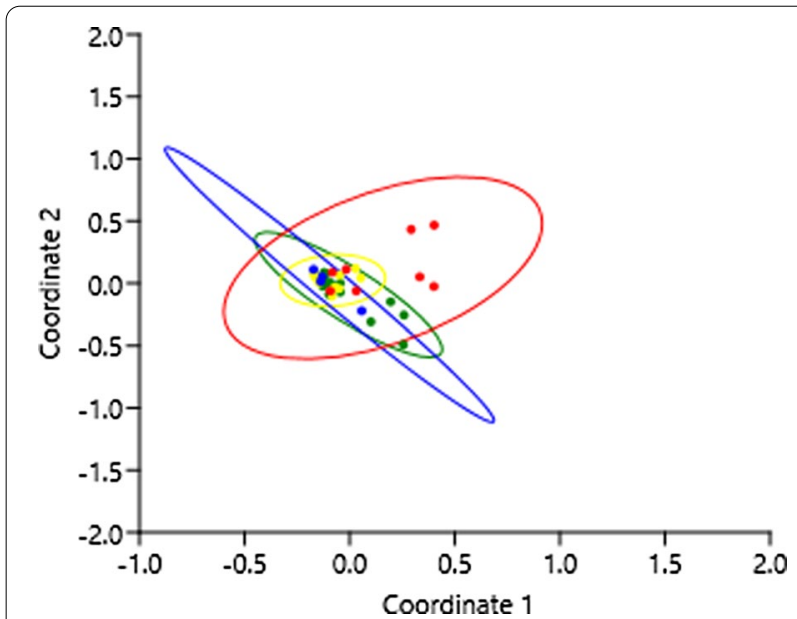

Fig. 5 Principal coordinate analysis ( $P C O A)$ showing the similarity between the species indicated by the 35 traders in the four mesoregions. Green = Mata; yellow = Agreste; blue= Borborema; red $=$ Sertão have been commonly documented in markets of nearby regions, such as in Pernambuco, although $P$. granatum and $Z$. officinale usually presented relatively low RI values compared to what was observed in our study $[10,18,23]$.

The greater use of medicinal plants to treat diseases of the digestive and respiratory systems has often been reported in ethnobotanical studies $[3,14,15,21]$ and explained by the fact that these diseases are most commonly affecting the population [3, 15]. The emphasis on endocrine, nutritional, and metabolic diseases might partly be explained due to plant use for weight loss (Table 1), which, according to the traders, is also a consequence of the growing interest of customers in using plants that aid in losing weight and keeping a good shape. This has been related to the current habits of society, which tends to be sedentary and ingest highly caloric foods, becoming obese, and social media and television promoting the sale of medicinal plants for losing weight [44-46]. 


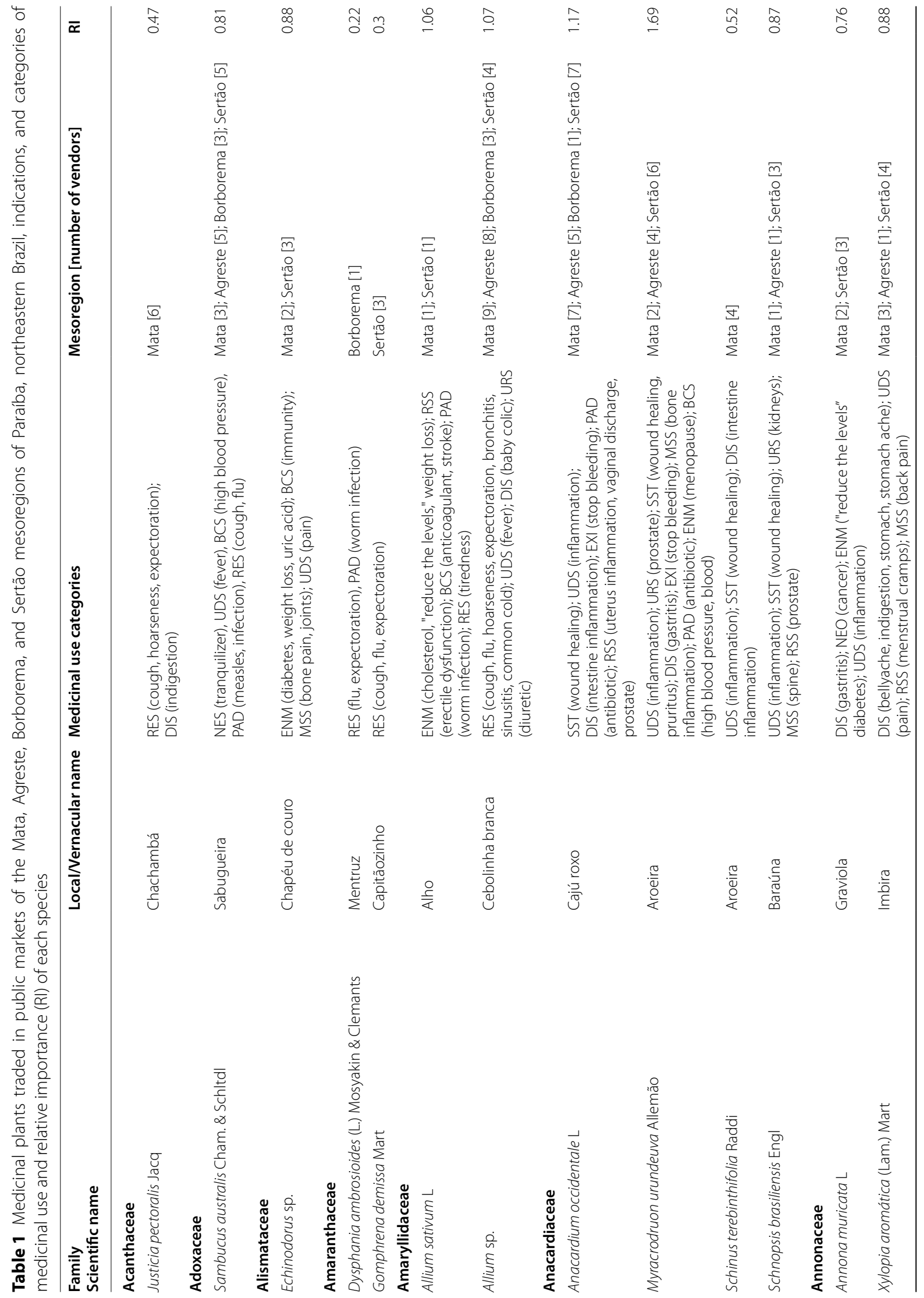


da Costa Ferreira et al. Journal of Ethnobiology and Ethnomedicine $\quad$ (2021) 17:70

Page 9 of 24

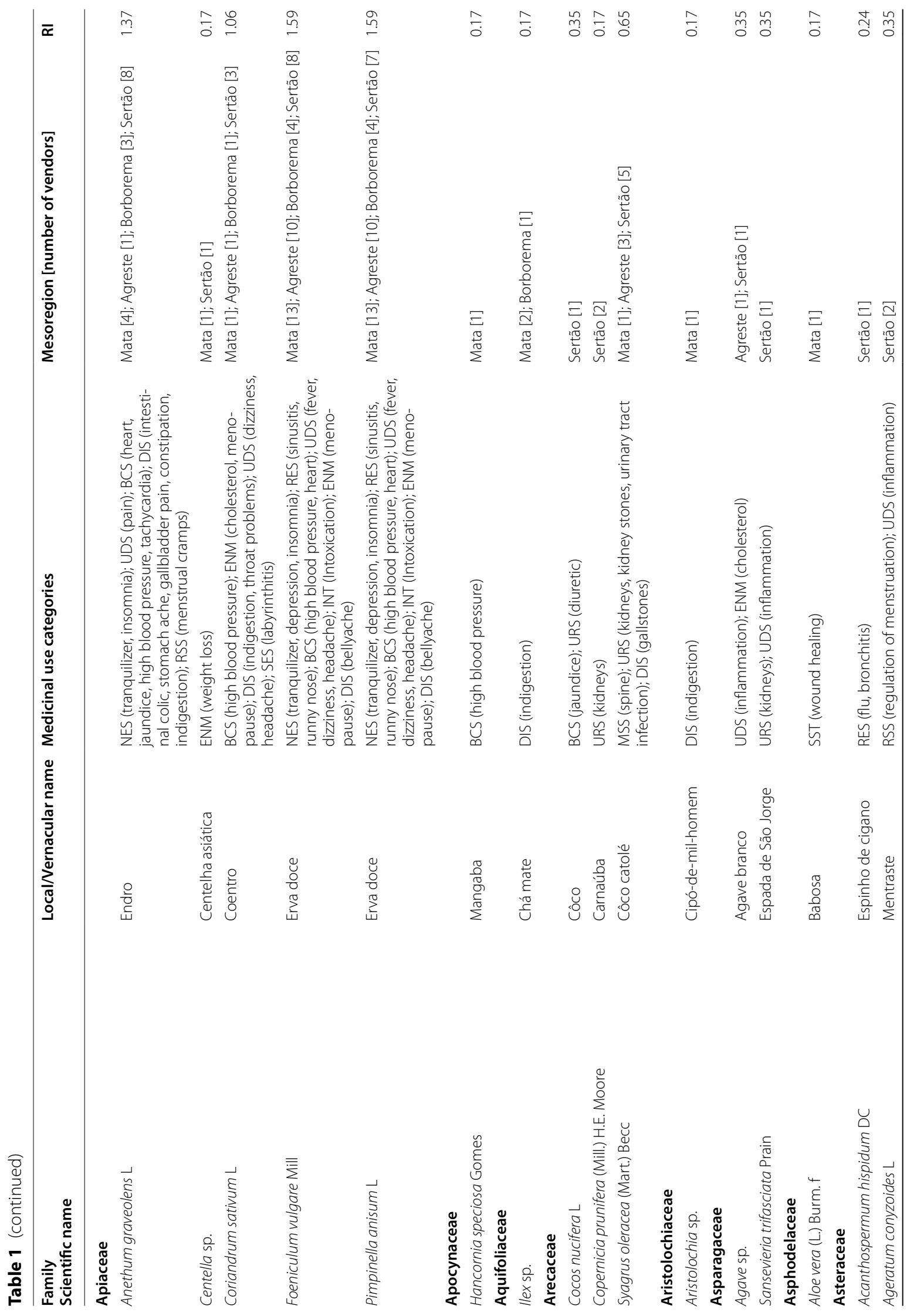




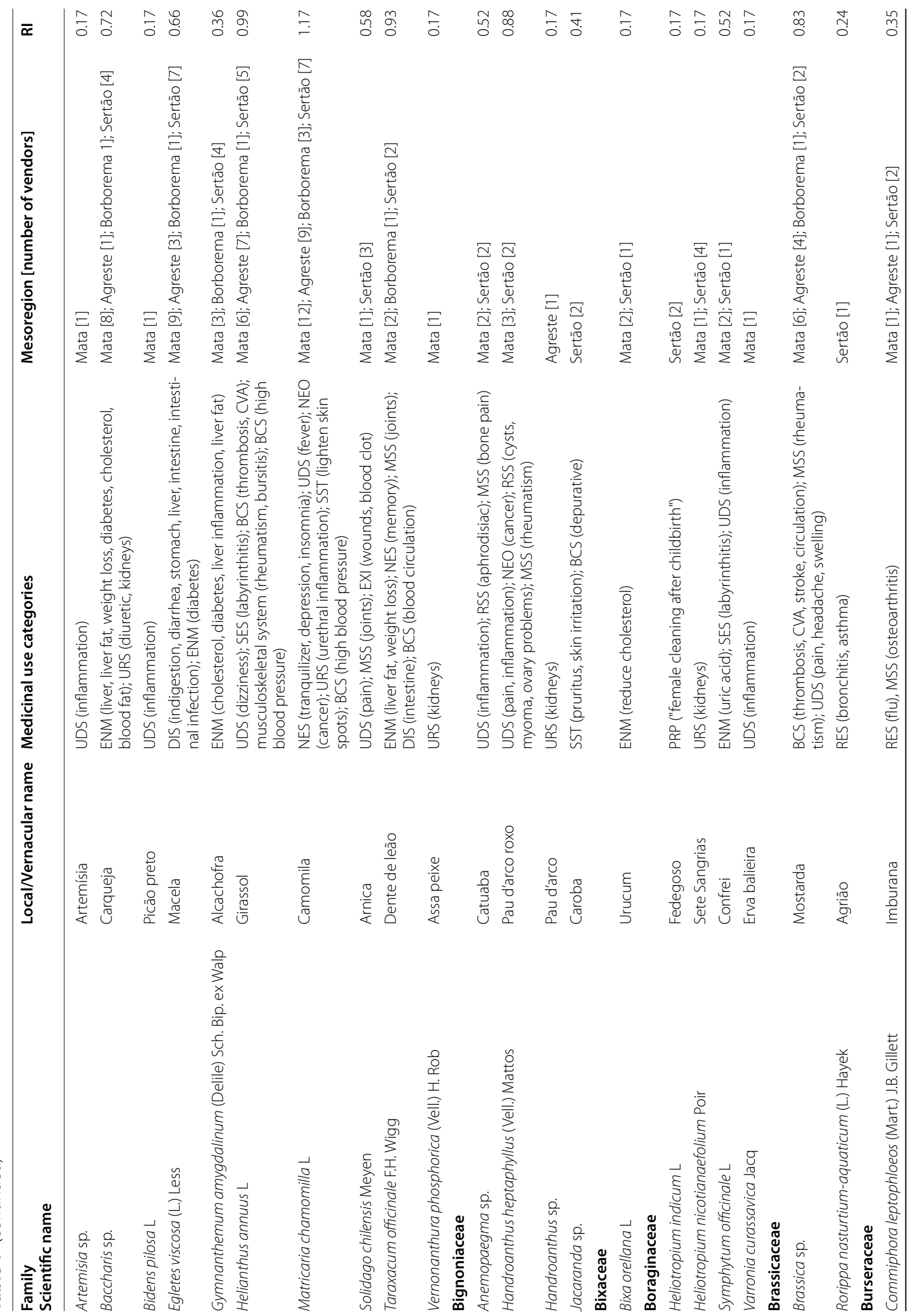




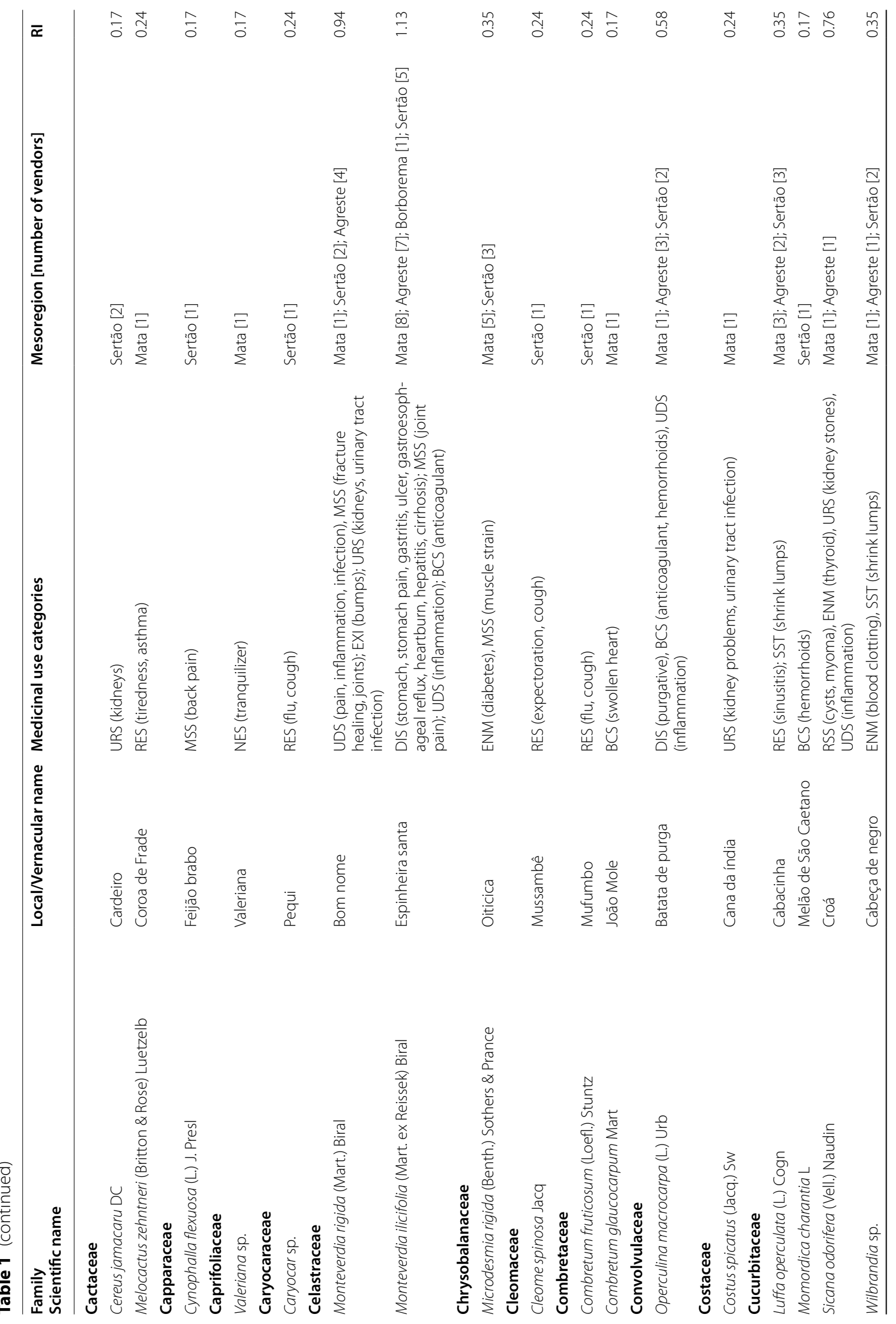




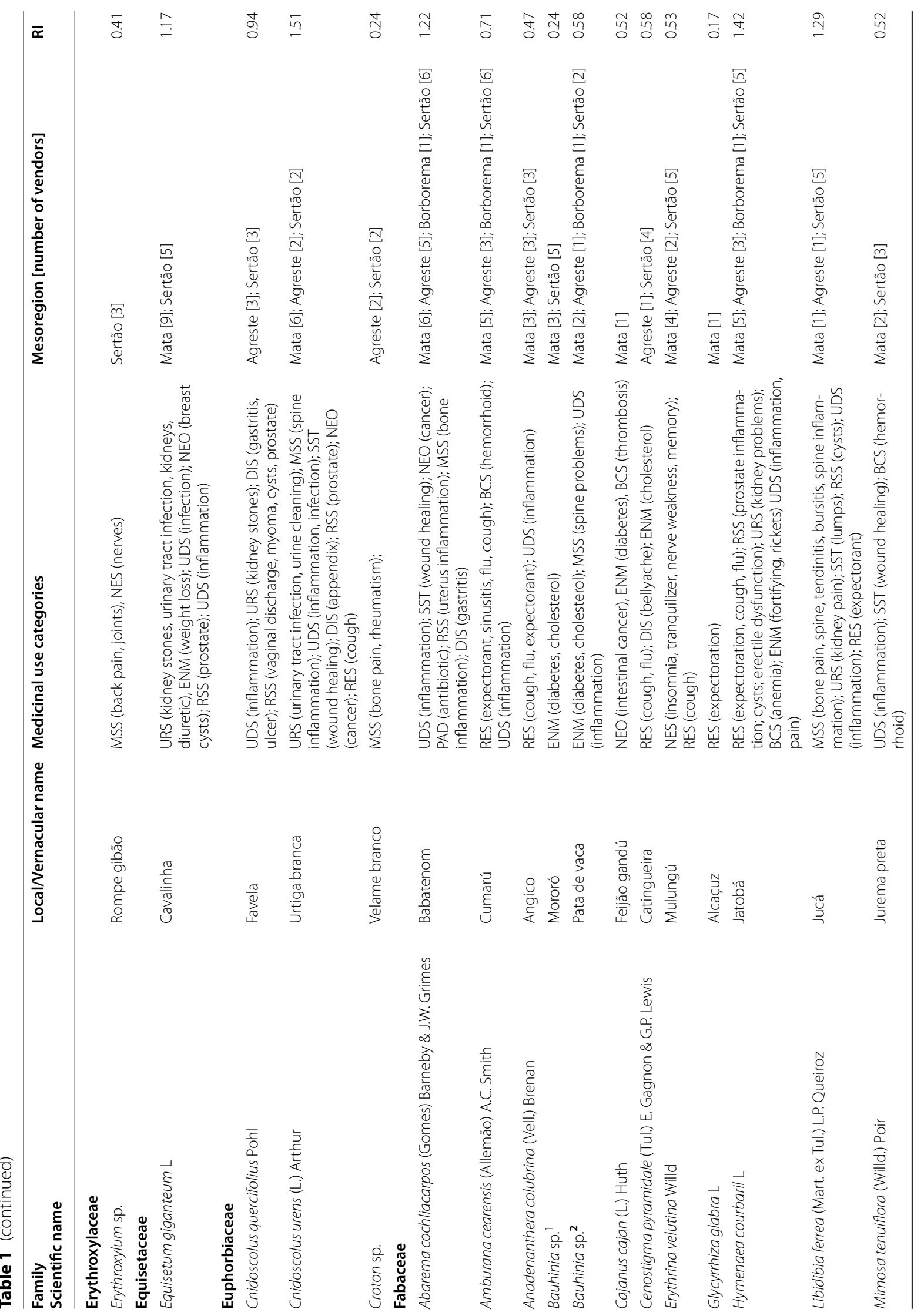


da Costa Ferreira et al. Journal of Ethnobiology and Ethnomedicine $\quad$ (2021) 17:70

Page 13 of 24

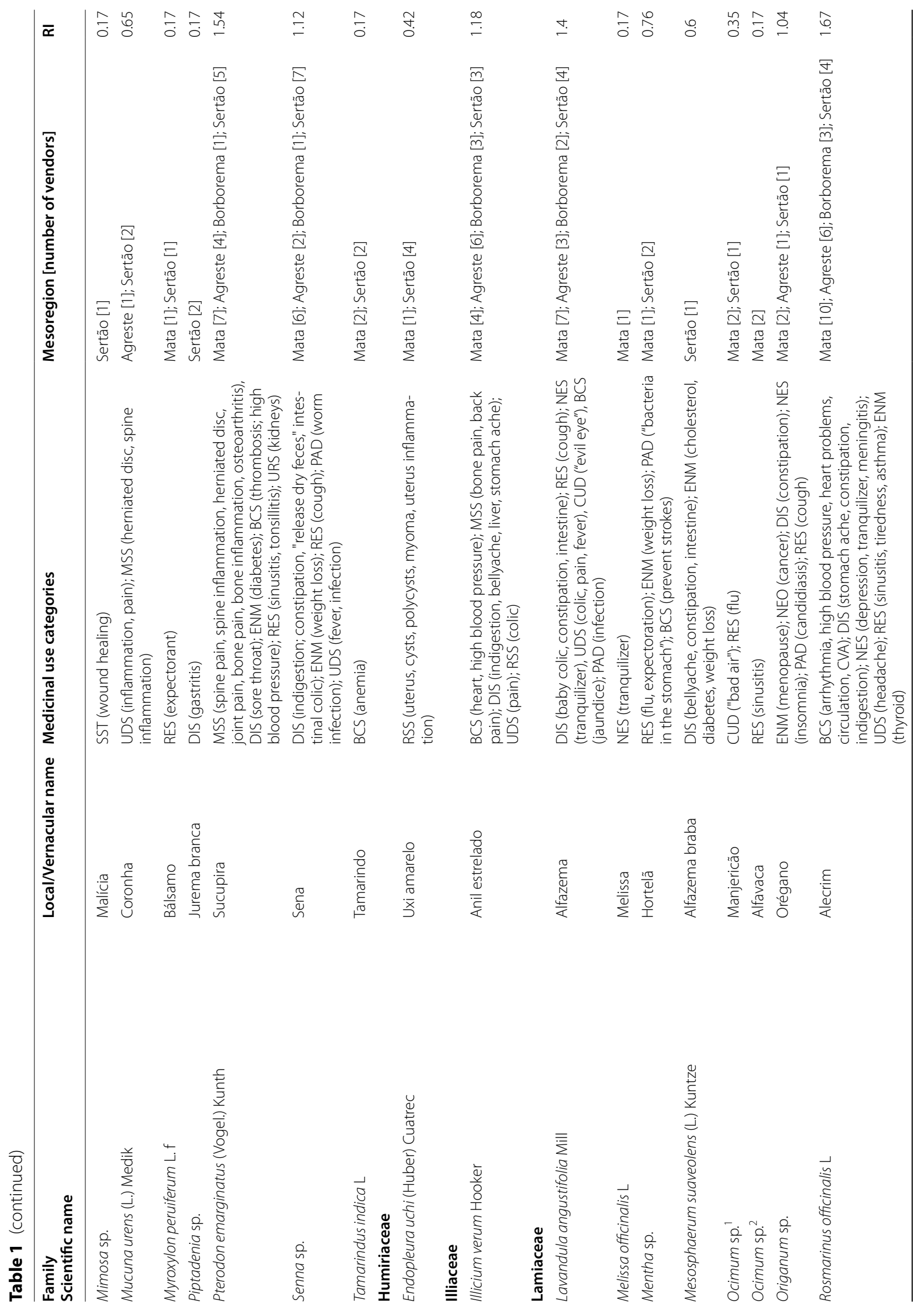


da Costa Ferreira et al. Journal of Ethnobiology and Ethnomedicine $\quad$ (2021) 17:70

Page 14 of 24

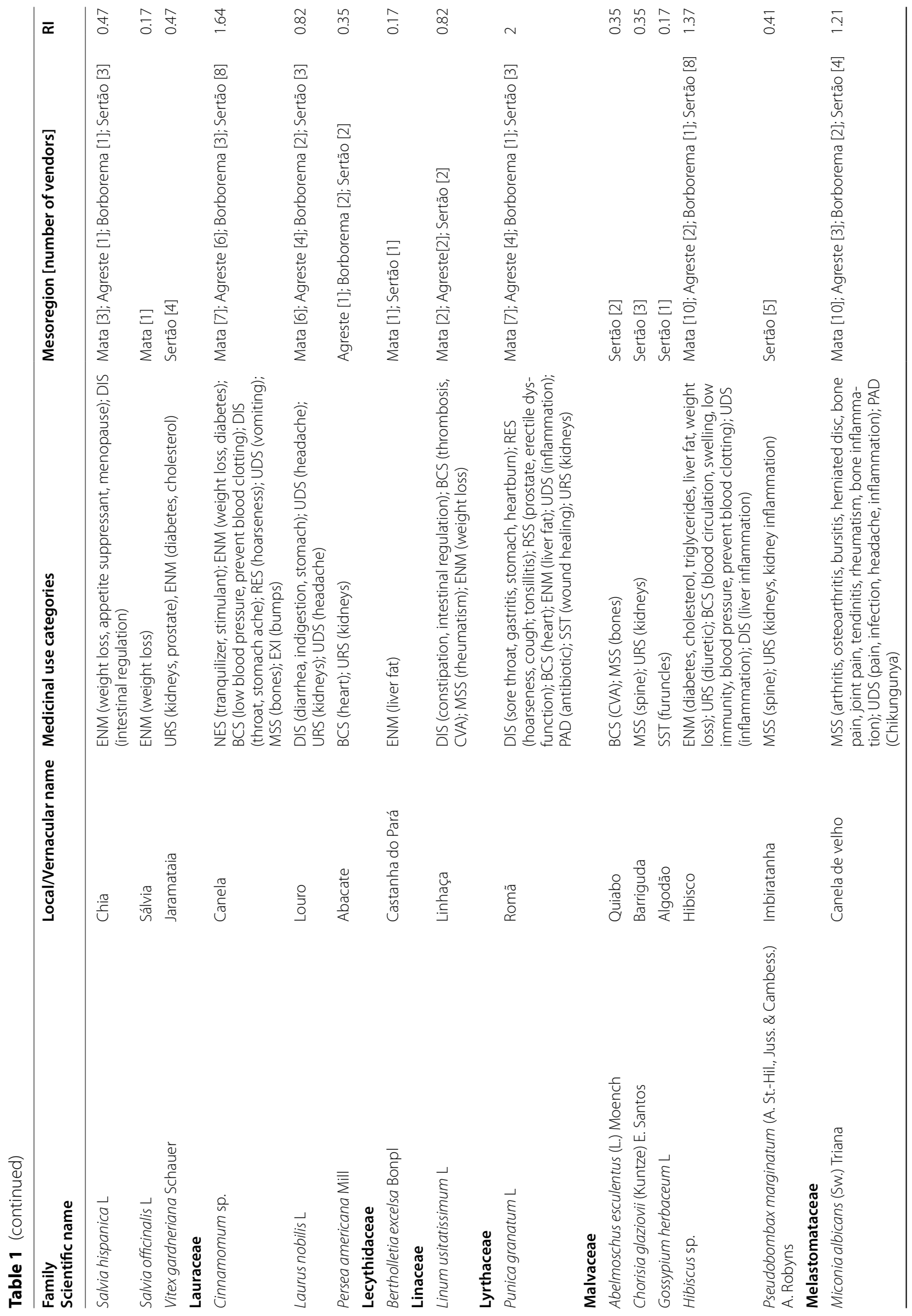




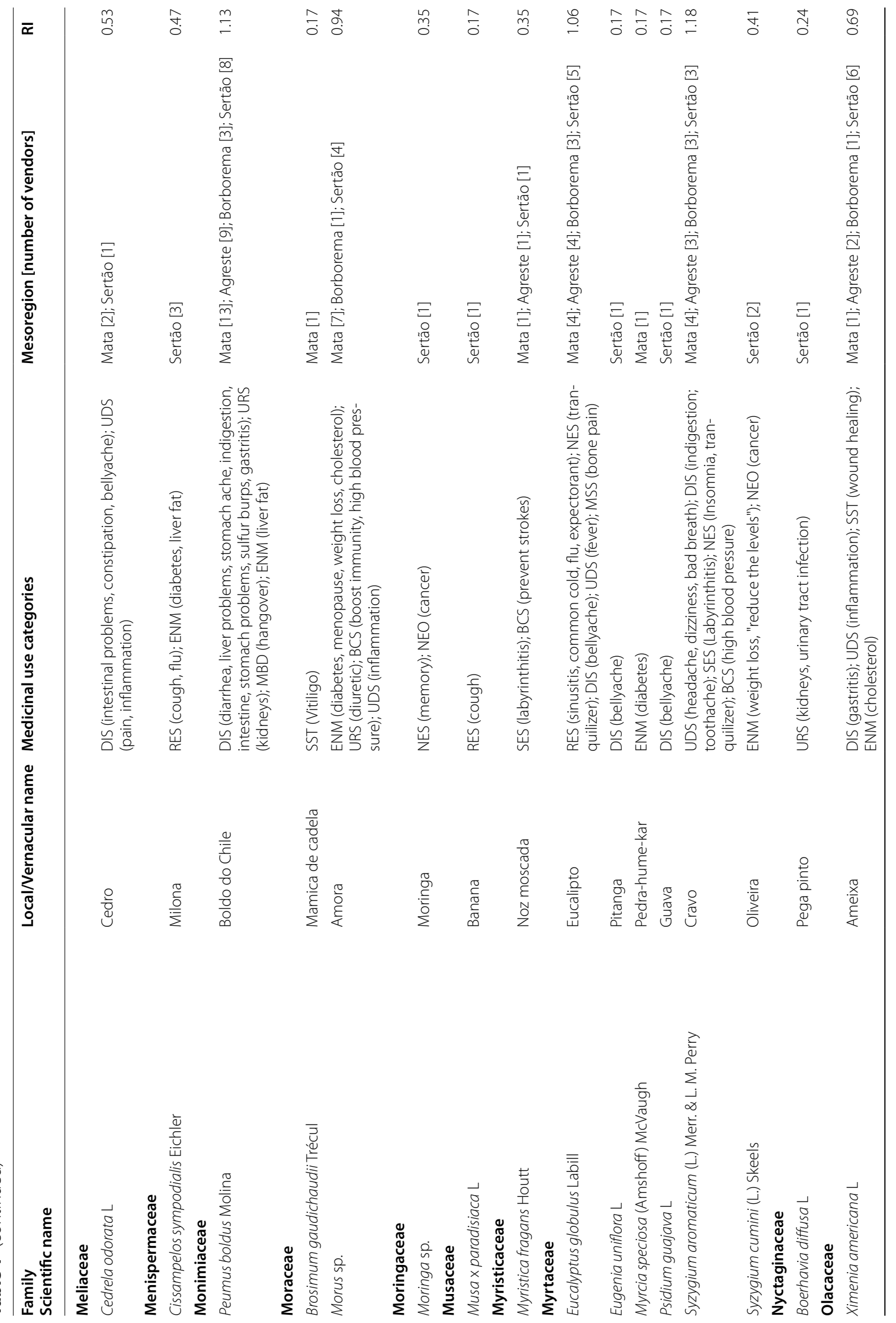




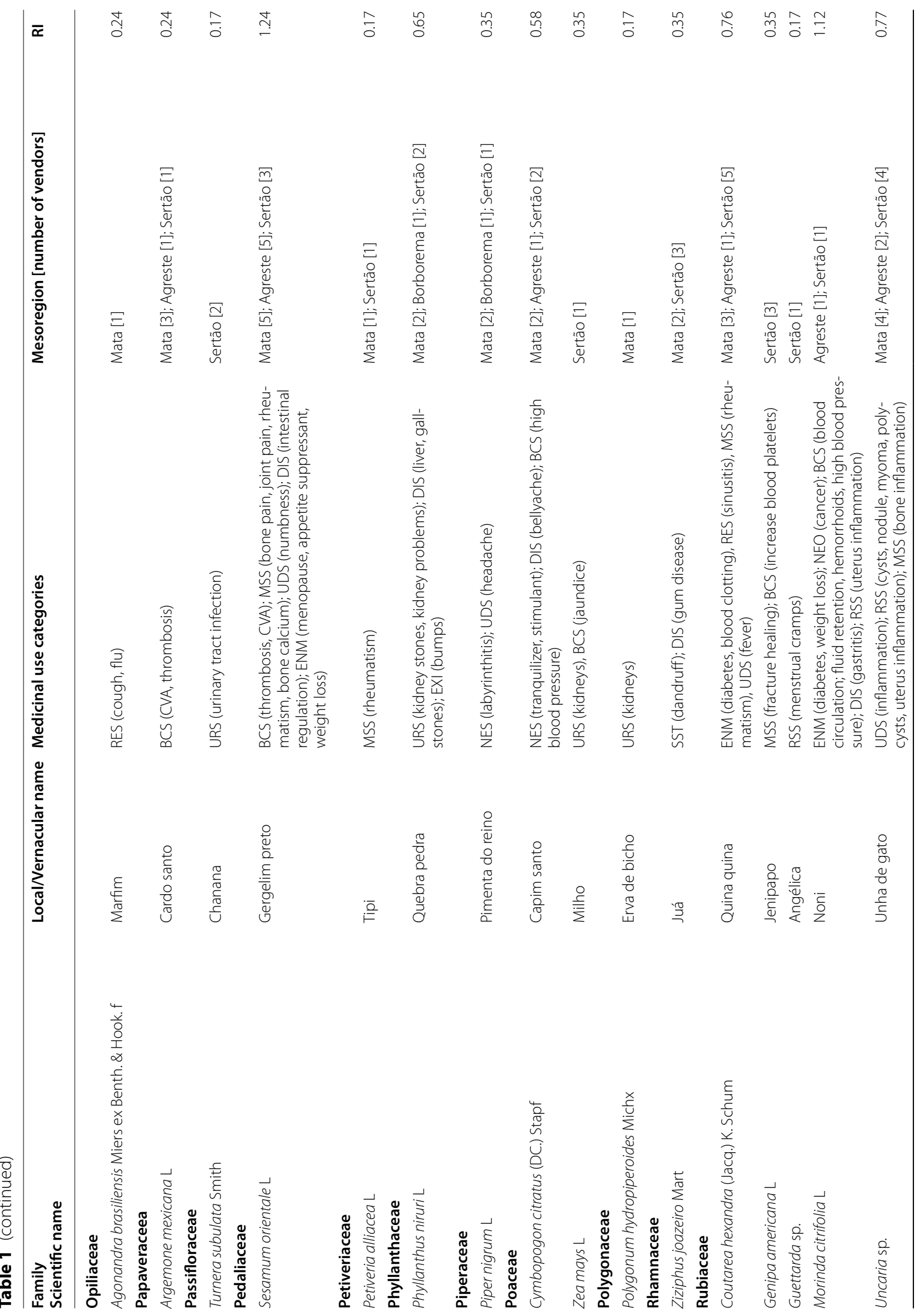




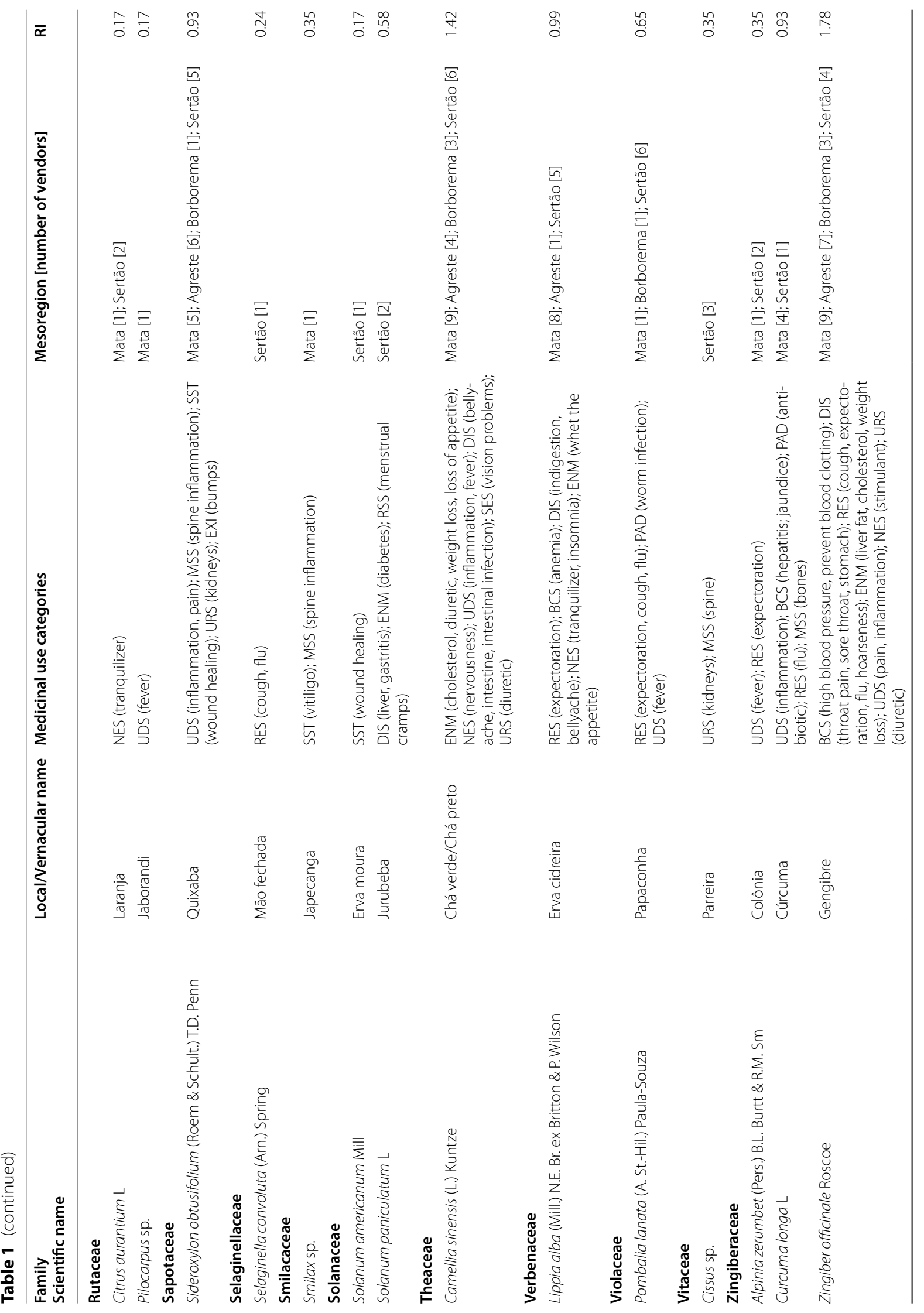




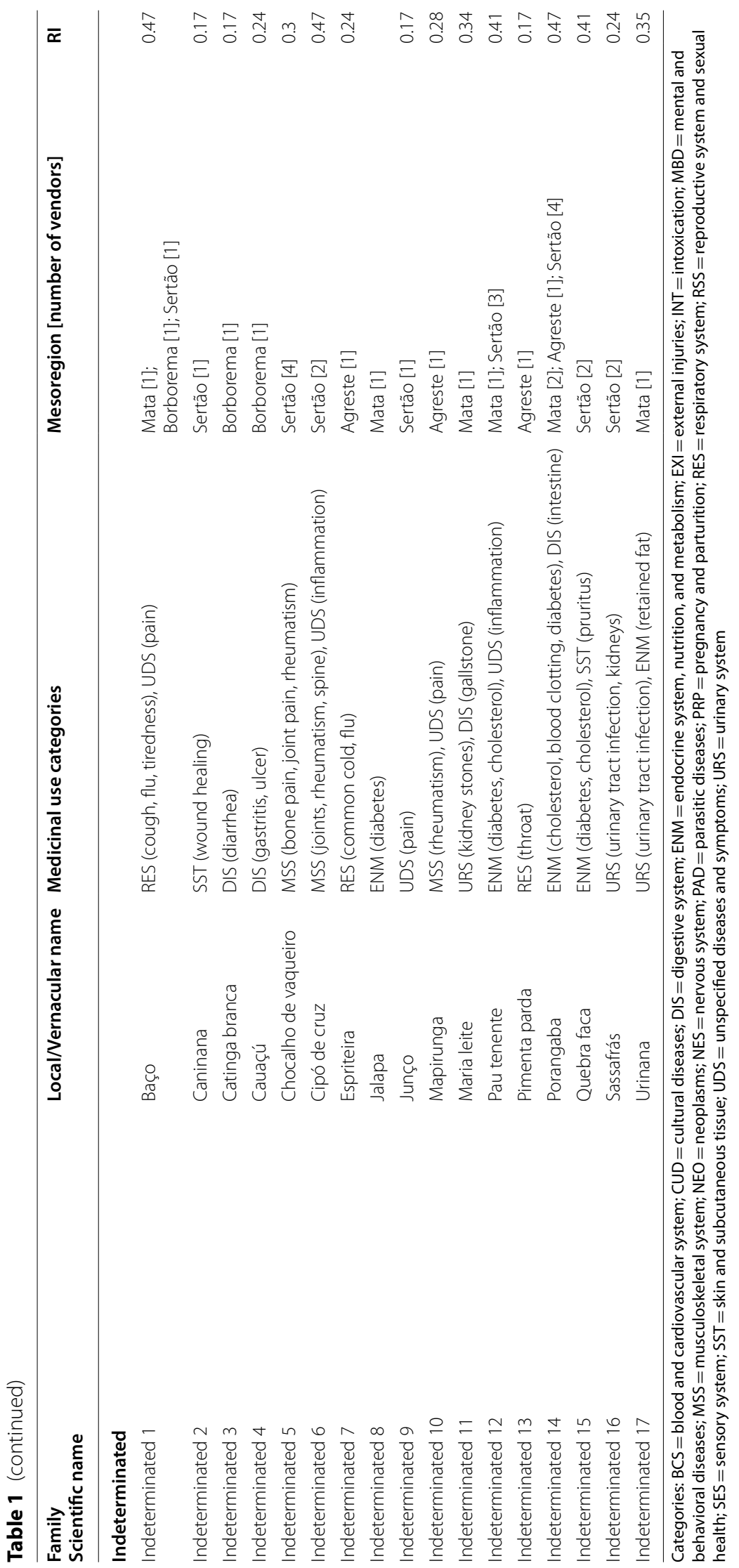


Table 2 Medicinal plants of high relative importance in public markets of different mesoregions in the state of Paraíba, northeastern Brazil

\begin{tabular}{|c|c|c|c|c|c|}
\hline Species & Origin & RI & Species & Origin & RI \\
\hline Punica granatum & E & 2 & Abarema cochliacarpos & $\mathrm{N}$ & 1.22 \\
\hline Zingiber officinale & E & 1.78 & Miconia albicans & $\mathrm{N}$ & 1.21 \\
\hline Myracrodruon urundeuva & N & 1.69 & Illicium verum & E & 1.18 \\
\hline Rosmarinus officinalis & $E$ & 1.67 & Syzygium aromaticum & E & 1.18 \\
\hline Cinnamomum sp. & $\mathrm{E}$ & 1.64 & Anacardium occidentale & N & 1.17 \\
\hline Foeniculum vulgare & $\mathrm{E}$ & 1.59 & Matricaria chamomilla & E & 1.17 \\
\hline Pimpinella anisum & $E$ & 1.59 & Equisetum giganteum & N & 1.17 \\
\hline Pterodon emarginatus & $\mathrm{N}$ & 1.54 & Monteverdia ilicifolia & N & 1.13 \\
\hline Cnidoscolus urens & $\mathrm{N}$ & 1.51 & Peumus boldus & E & 1.13 \\
\hline Hymenaea courbaril & $\mathrm{N}$ & 1.42 & Senna sp. & N & 1.12 \\
\hline Camellia sinensis & $E$ & 1.42 & Morinda citrifolia & E & 1.12 \\
\hline Lavandula angustifolia & $\mathrm{E}$ & 1.4 & Allium sp. & $E$ & 1.07 \\
\hline Anethum graveolens & $\mathrm{E}$ & 1.37 & Allium sativum & $E$ & 1.06 \\
\hline Hibiscus sp. & $E$ & 1.37 & Coriandrum sativum & $E$ & 1.06 \\
\hline Libidibia ferrea & N & 1.29 & Eucalyptus globulus & E & 1.06 \\
\hline Sesamum orientale & $E$ & 1.24 & Origanum sp. & $E$ & 1.04 \\
\hline
\end{tabular}

$\mathrm{N}=$ species native to Brazil. $\mathrm{E}=$ exotic species. $\mathrm{RI}=$ relative importance

In most cases, the medicinal use of leaves, bark, and seeds (Fig. 3) was recorded, similar to several other studies $[7,30,47]$. Previously, a greater use of leaves and herbaceous plants in wetter regions, such as the Atlantic Forest, has been commonly registered [4, 48, 49], while in drier regions, such as the Caatinga, a predominance of the use of barks and woody plants has been shown [3, 50], highlighting a relationship with the loss of foliage in the vegetation during the drier periods [16]. This apparent correspondence between the most used plant parts and the environment can also be seen in other studies conducted in dry $[6,8,51]$ and wetter environments $[20$, 33]. However, in the most cases of this study, it was not possible to establish a similar relationship between the environment and the most traded plant parts, and the Agreste was the only region where the bark was the main plant structure traded. The leaves were the main plant part in the remaining mesoregions, even in drier areas, where a more significant bark trade would have been expected. Agreste is an ecotone between dry and humid regions, despite the predominance of the semiarid area in this mesoregion. The bark commercialization in this mesoregion suggests a trade preference of the native species, and the bark can be obtained from tree species of the Caatinga (usually without leaves in the dry season). Cultural practices and the local knowledge heritance can support this use and the consumption of these species. A possible explanation for that is the dynamism of medicinal plant trade, which involves not only the local plant species in the studied markets but also species from other regions and even imported from other countries, since, as observed here, most species with high relative importance were exotic.

\section{Similarity between the mesoregions}

Interestingly, the Agreste mesoregion, geographically located in a transition area between the Atlantic Forest and the Caatinga, fell in the center of the graph, sharing its limits with all remaining mesoregions. The intensity of trading of Atlantic and Caatinga species and the commercialized exotic species as well indicates that this region, as an ecotone, also favors the exchange of knowledge. This leads us to suggest that the Agreste mesoregion represents a not only as a transition area for vegetation, but also of knowledge and practice in the use of (medicinal) plants in comparison with the remaining mesoregions. In this context, besides being an important ecological area for conservation, the ecotone can also represent a region that demands attention for cultural proposes. This perspective could be an interesting guiding tool for future research involving the trade in medicinal plants.

Considering the relatively small territory of the state of Paraíba $\left(56,585 \mathrm{~km}^{2}\right)$ [35], it may be inferred that there is a permutation of knowledge and traded species between the different regions. Although a study with similarity analysis between different phytophysiognomies in the states of Paraíba and Pernambuco has not found similarity between the studied phytophysiognomies [52], it is worth noting that, in addition to the possibility of permutation of native species of different phytophysiognomies, 
Table 3 Percentage of informants that reported the absence of some species during the interview period for each studied mesoregion. Blank cells indicate that the species was not recorded in the mesoregion at any time of the year. $1^{\circ}=$ August-October $2017 ; 2^{\circ}=$ November 2017-January 2018; $3^{\circ}=$ February-April 2018; $4^{\circ}=$ May-July 2018

\begin{tabular}{|c|c|c|c|c|c|c|c|c|c|c|c|c|c|c|c|c|}
\hline \multirow[t]{2}{*}{ Species } & \multicolumn{4}{|c|}{$\begin{array}{l}\text { Mata } \\
(\mathrm{N}=13)\end{array}$} & \multicolumn{4}{|c|}{$\begin{array}{l}\text { Agreste } \\
(\mathrm{N}=10)\end{array}$} & \multicolumn{4}{|c|}{$\begin{array}{l}\text { Borborema } \\
(\mathrm{N}=4)\end{array}$} & \multicolumn{4}{|c|}{$\begin{array}{l}\text { Sertão } \\
(\mathrm{N}=8)\end{array}$} \\
\hline & $1^{\circ}$ & $2^{\circ}$ & $3^{\circ}$ & $4^{\circ}$ & $1^{\circ}$ & $2^{\circ}$ & $3^{\circ}$ & $4^{\circ}$ & $1^{\circ}$ & $2^{\circ}$ & $3^{\circ}$ & $4^{\circ}$ & $1^{\circ}$ & $2^{\circ}$ & $3^{\circ}$ & $4^{\circ}$ \\
\hline Abarema cochliacarpos & 7.69 & - & - & - & 30 & 20 & 20 & 10 & - & - & - & - & - & 12.5 & - & - \\
\hline Agave sp. & & & & & - & - & - & 10 & & & & & - & - & - & - \\
\hline Ageratum conyzoides & & & & & & & & & & & & & - & 12.5 & 12.5 & 12.5 \\
\hline Allium sp. & 7.69 & - & 15.38 & 7.69 & - & 30 & 10 & 10 & - & - & 25 & - & - & 25 & 12.5 & 25 \\
\hline Aloevera & 7.69 & - & 15.38 & 7.69 & & & & & 25 & - & 25 & - & & & & \\
\hline Alpinia zerumbet & 15.38 & 7.69 & - & - & & & & & & & & & - & 12.5 & - & - \\
\hline Amburana cearensis & 15.38 & - & 7.69 & 15.38 & 10 & - & 30 & - & - & - & - & - & - & - & - & - \\
\hline Anacardium occidentale & - & - & 7.69 & - & - & - & 10 & 10 & - & - & - & - & - & 12.5 & 12.5 & - \\
\hline Anadenanthera colubrina & 15.38 & - & - & 7.69 & - & 10 & - & - & & & & & - & - & - & - \\
\hline Anemopaegma sp. & 7.69 & 7.69 & - & - & & & & & & & & & - & - & 12.5 & - \\
\hline Anethum graveolens & 23.07 & - & - & - & - & - & 20 & 20 & - & - & - & - & - & 12.5 & 12.5 & - \\
\hline Annona muricata & 7.69 & - & 15.38 & - & - & - & - & - & - & - & - & - & - & - & - & - \\
\hline Baccharis sp. & 15.38 & 7.69 & 15.38 & - & - & - & - & - & - & - & 50 & - & 25 & - & 12.5 & - \\
\hline Bahuinia sp. $^{2}$ & 7.69 & 7.69 & - & - & 10 & - & 10 & - & - & - & - & - & - & - & - & - \\
\hline Bertholletia excelsa & - & - & 7.69 & - & & & & & & & & & - & - & - & - \\
\hline Boerhavia coccinea & - & - & 7.69 & - & & & & & & & & & - & - & 12.5 & 12.5 \\
\hline Brassica sp. & - & - & - & - & 10 & 10 & - & - & - & - & - & - & - & - & 12.5 & 12.5 \\
\hline Camellia sinensis & 7.69 & - & - & - & 10 & 20 & - & - & - & - & 25 & 25 & 25 & 12.5 & - & 12.5 \\
\hline Caryocar sp. & & & & & & & & & & & & & - & - & 12.5 & 12.5 \\
\hline Cenostigma pyramidale & & & & & - & - & - & - & & & & & - & 12.5 & - & 12.5 \\
\hline Centella sp. & - & - & - & - & & & & & & & & & - & 12.5 & 12.5 & 12.5 \\
\hline Cissus sp. & & & & & & & & & & & & & - & - & 12.5 & - \\
\hline Chorisia glaziovii & & & & & & & & & & & & & - & 12.5 & 12.5 & 12.5 \\
\hline Cissampelos sympodialis & & & & & & & & & & & & & - & - & - & 25 \\
\hline Cnidoscolus urens & - & - & 7.69 & - & 10 & - & 10 & - & & & & & - & 12.5 & - & - \\
\hline Cnidoscolus quercifolius & & & & & - & - & 10 & - & 25 & 25 & 25 & - & - & - & - & - \\
\hline Cocos nucifera & & & & & & & & & & & & & - & 12.5 & - & - \\
\hline Combretum fruticosum & & & & & & & & & & & & & - & - & 12.5 & - \\
\hline Copernicia prunifera & & & & & & & & & & & & & - & 12.5 & - & - \\
\hline Croton sp. & & & & & - & - & 10 & - & & & & & - & - & - & - \\
\hline Cymbopogon citratus & - & - & - & - & - & 10 & - & - & 25 & - & - & - & - & - & - & - \\
\hline Cynophalla flexuosa & & & & & & & & & & & & & - & 12.5 & 12.5 & - \\
\hline Erythrina velutina & 15.38 & - & - & - & - & - & - & - & & & & & - & - & 12.5 & 12.5 \\
\hline Eucalyptus globulus & - & - & - & - & - & - & - & - & - & - & - & - & - & - & - & - \\
\hline Foeniculum vulgare & 38.46 & 7.69 & - & - & - & - & - & - & 25 & 50 & - & - & 12.5 & - & - & - \\
\hline Glycyrrhiza glabra & - & - & - & 7.69 & & & & & & & & & & & & \\
\hline Helianthus annuus & - & - & - & - & - & - & 10 & - & - & - & 25 & - & - & - & - & - \\
\hline Hibiscus sp. & 7.69 & - & - & - & - & - & - & 10 & - & - & - & - & - & 12.5 & - & - \\
\hline Hymenaea courbaril & 23.07 & - & 7.69 & 7.69 & - & - & - & - & - & - & 25 & - & - & - & - & - \\
\hline Illicium verum & 15.38 & - & 7.69 & 7.69 & - & - & 30 & 10 & - & - & - & - & - & - & - & - \\
\hline Lavandula angustifolia & 7.69 & - & 7.69 & - & - & - & - & 10 & - & - & 25 & - & 12.5 & - & - & - \\
\hline Libidibia ferrea & 15.38 & 7.69 & - & - & 20 & 10 & 10 & - & & & & & - & - & - & - \\
\hline Licania rigida & 15.38 & 15.4 & - & - & & & & & 25 & - & - & - & 12.5 & - & 12.5 & - \\
\hline Lippia alba & 7.69 & - & - & 7.69 & - & - & - & - & & & & & - & 12.5 & - & - \\
\hline Luffa operculata & 7.69 & - & - & - & 10 & - & 10 & - & & & & & 12.5 & - & - & - \\
\hline Maytenus rigida & - & - & - & - & - & - & - & - & & & & & - & - & 12.5 & - \\
\hline
\end{tabular}


Table 3 (continued)

\begin{tabular}{|c|c|c|c|c|c|c|c|c|c|c|c|c|c|c|c|c|}
\hline \multirow[t]{2}{*}{ Species } & \multicolumn{4}{|c|}{$\begin{array}{l}\text { Mata } \\
(\mathrm{N}=13)\end{array}$} & \multicolumn{4}{|c|}{$\begin{array}{l}\text { Agreste } \\
(\mathrm{N}=10)\end{array}$} & \multicolumn{4}{|c|}{$\begin{array}{l}\text { Borborema } \\
(\mathrm{N}=4)\end{array}$} & \multicolumn{4}{|c|}{$\begin{array}{l}\text { Sertão } \\
(\mathrm{N}=8)\end{array}$} \\
\hline & $1^{\circ}$ & $2^{\circ}$ & $3^{\circ}$ & $4^{\circ}$ & $1^{\circ}$ & $2^{\circ}$ & $3^{\circ}$ & $4^{\circ}$ & $1^{\circ}$ & $2^{\circ}$ & $3^{\circ}$ & $4^{\circ}$ & $1^{\circ}$ & $2^{\circ}$ & $3^{\circ}$ & $4^{\circ}$ \\
\hline Mentha sp. & - & - & - & - & & & & & 25 & 25 & 25 & - & - & - & - & - \\
\hline Miconia albicans & - & - & 7.69 & 7.69 & - & - & 10 & - & - & - & - & - & - & - & - & - \\
\hline Monteverdia ilicifolia & - & - & - & 7.69 & - & 10 & - & - & - & - & - & - & - & - & - & 12.5 \\
\hline Morus sp. & 7.69 & - & - & 7.69 & & & & & - & - & - & - & - & - & - & - \\
\hline Musa x paradisíaca & & & & & & & & & & & & & - & 12.5 & - & 12.5 \\
\hline Myracrodruon urundeuva & - & - & - & - & 30 & 10 & 20 & - & & & & & - & - & - & - \\
\hline Persea americana & & & & & - & - & - & - & - & - & - & - & - & - & - & 12.5 \\
\hline Phyllanthus niruri & 23.07 & 15.4 & - & 30.77 & 10 & - & - & 10 & - & - & 25 & - & - & - & - & - \\
\hline Pimpinella anisum & - & - & - & 7.69 & - & - & - & - & - & - & - & - & - & - & - & - \\
\hline Pombalia lanata & - & - & 23.08 & - & & & & & - & - & - & - & - & 12.5 & 25 & 12.5 \\
\hline Pterodon emarginatus & 7.69 & 7.69 & 7.69 & - & 10 & 10 & 20 & 10 & 25 & - & - & - & - & - & - & - \\
\hline Punica granatum & 7.69 & - & - & - & 10 & - & - & - & - & - & - & - & - & - & - & 25 \\
\hline Rosmarinus officinalis & - & - & 7.69 & - & 10 & - & - & - & - & - & - & - & 12.5 & 12.5 & 12.5 & - \\
\hline Salvia hispânica & 7.69 & - & - & - & - & 10 & - & - & - & - & 25 & - & - & - & 12.5 & - \\
\hline Sambucus australis & 7.69 & - & - & - & 10 & - & 10 & 10 & - & - & 25 & 25 & - & - & - & - \\
\hline Schnopsis brasiliensis & - & - & - & - & - & 10 & 10 & 10 & & & & & - & - & 12.5 & 12.5 \\
\hline Senna sp. & 7.69 & - & 7.69 & - & 10 & - & 10 & - & - & - & - & - & - & - & - & - \\
\hline Sesamum orientale & - & - & - & - & 10 & - & - & - & 25 & 25 & 25 & - & - & - & 12.5 & 25 \\
\hline Sideroxylon obtusifolium & - & - & - & - & - & 10 & 10 & 10 & - & - & 25 & - & - & - & - & - \\
\hline Solanum americanum & & & & & & & & & & & & & - & 12.5 & - & - \\
\hline Symphytum officinale & - & - & - & - & & & & & & & & & - & - & 12.5 & 12.5 \\
\hline Syzygium cumini & - & - & - & - & - & - & - & - & - & - & - & - & - & 12.5 & - & - \\
\hline Tamarindus indica & 7.69 & 7.69 & - & - & & & & & & & & & - & 12.5 & 12.5 & 12.5 \\
\hline Taraxacum officinale & - & - & - & - & & & & & - & - & 25 & - & 25 & 25 & 12.5 & 12.5 \\
\hline Valeriana sp. & - & 7.69 & - & - & & & & & & & & & & & & \\
\hline Wilbrandia sp. & - & - & - & 7.69 & - & - & - & - & & & & & - & - & - & - \\
\hline Ximenia americana & - & - & - & - & - & - & - & - & - & - & 25 & - & - & - & - & - \\
\hline Zingiber officinale & - & - & 7.69 & - & - & - & - & - & - & - & - & - & - & - & 12.5 & - \\
\hline Ziziphus joazeiro & - & - & - & 7.69 & & & & & & & & & - & 12.5 & - & - \\
\hline
\end{tabular}

the use of exotic species is a factor that collaborates for a greater sharing of species, even in so different areas as the Atlantic Forest and the Caatinga.

\section{Temporal variation in the medicinal plant trade}

It was impossible to establish a relationship between the unavailability of any species during some period and the mesoregion, given that when one species was unavailable in one trade location (market stand), it could usually be found in other locations of the same market. While there might be a relationship between plant habit and availability, given most species that showed some period of unavailability are herbaceous, similar to other studies [10], most species are sold dried, giving the traders the possibility to simply acquire and stock the material to avoid a lack of the product [20], although at times traders simply might not have the financial resources to stock material.
In some cases, the informants stated that Foeniculum vulgare, according to them, cultivated in the Brejo and Curimataú areas (Agreste Mesoregion), was not available during some periods. A possible explanation for species unavailability in some cases could be traced to the recent sale of the whole stock by a trader, or the lack of interest by the trader in stocking a particular product given the low demand.

It was also possible to note the incorporation of a new species into the plant trade during our study: In the first stage of the interviews, Miconia albicans was only found in a few places of the Mata and Sertão mesoregions, and then, a fast spread of this species in the market was observed. Although being a native species and, according to some informants, common in woody areas of both the Atlantic Forest and the Caatinga, its medicinal use was not well known until recently. According to the traders, 
a recent increase in the trade of this species occurred due to their recent promotion to treat pain and muscular and rheumatic diseases on the internet and television, which led increasing to a consumer demand. Previous ethnobotanical studies did record this species, but made no reference to its medicinal use [53-55]. Similar cases have also been reported for Hibiscus sp., Camellia sinensis, and Zingiber officinale, species that, according to the informants, began to be traded less than a decade ago, also influenced by the media and the Internet. In the contemporary world, traditional medicinal practices have often incorporated other knowledge, e.g., biomedical knowledge, in the globalization process, in this way affecting selection and transmission mechanisms of knowledge [56].

\section{Conclusions}

The inventory of medicinal plants available in the markets of Paraíba varies little throughout the year. In general, traders seem to keep permanent stocks of the main plants. Traders were also receptive to incorporating new plants into their stocks, which might be explained several factors, such as the influence of the media and the Internet, fostering the growing interest of customers in certain species.

It was impossible to establish a relationship between the periods of species absence in some trading locations and the mesoregion where this absence occurred. The absence during certain periods is probably more related to temporary unavailability or the impossibility for the trader to stock the product, or might even be related to environmental changes, which may influence species availability. It was not possible to establish a direct association between the climatic variations of each mesoregion and the plant part traded. The leaves were the more commercialized parts, even in the drier regions, except in the Agreste, an ecotone region, where the bark was the main part observed.

The Sertão mesoregion was the only one that showed a significant variation in the inventory of species sold by the traders. It is also interesting that the Agreste mesoregion, geographically located in an intermediate region between the Atlantic Forest and the Caatinga, showed an intermediate similarity pattern with the remaining mesoregions.

\section{Acknowledgements}

The authors would like to thank all local traders for their reception and for agreeing to participate in the study.

\section{Authors' contributions}

ECF collected and analyzed the data and wrote the manuscript, DDC and RFPL coordinated the field research and the writing of the manuscript, and RWB and NYPZ contributed to final write-up. All authors read and approved the final manuscript.

\section{Funding}

Data of the present study are derived from the first author's master's thesis, which received a scholarship from the Conselho Nacional de Desenvolvimento Científico e Tecnológico (CNPq).

\section{Availability of data and materials}

The datasets used and/or analyzed during the current study are available from the corresponding author on reasonable request.

\section{Declarations}

\section{Ethics approval and consent to participate}

The aim of this study was explained to each informant, who was then asked to sign a consent form, as required by the National Health Council and the Research Ethics Committee (Resolution 466/12). This research was approved by the Research Ethics Committee of the State University of Paraíba (Protocol No. 82943618.0.0000.5188). The authors interviewed 35 informants, who were informed of the aim of this scientific research and agreed to sign an informed consent form, according to necessary standards, and as described in the methodology through the protocol number.

\section{Consent for publication}

The participants who signed the consent form were aware that this scientific research could be published in the academic milieu.

\section{Competing interests}

The authors declare that they have no competing interests.

\section{Author details}

'Laboratório de Ecologia Terrestre, Dept. de Sistemática E Ecologia, Centro de Ciências, Exatas e da Natureza, Universidade Federal da Paraíba, João Pessoa, PB 58051-900, Brazil. 2Programa de Pós-Graduação Em Desenvolvimento E Meio Ambiente, PRODEMA, Universidade Federal da Paraíba, João Pessoa, PB 58051-900, Brazil. Instituto de Biociências, Universidade Federal Do Mato Grosso Do Sul, Campo Grande 79070-900, Brazil. ${ }^{4}$ Department of Ethnobotany, Institute of Botany and Bakuriani Alpine Botanical Garden, Ilia State University, 1 Botanical Str., 0105 Tbilisi, Georgia.

Received: 24 May 2021 Accepted: 25 November 2021

Published online: 19 December 2021

\section{References}

1. Ribeiro RV, Bieski IGC, Balogun SO, Martins DT de O. Ethnobotanical study of medicinal plants used by Ribeirinhos in the North Araguaia microregion, Mato Grosso, Brazil. J Ethnopharmacol. 2017;205:69-102.

2. Silva TC, Silva JM, Ramos MA. What factors guide the selection of medicinal plants in a local pharmacopoeia? A case study in a rural community from a historically transformed Atlantic Forest landscape. Evidence-based Complement Altern Med. Hindawi; 2018;2018.

3. Coutinho PC, Soares ZA, Ferreira EC, Souza DV, Oliveira RS, Lucena RFP. Knowledge and use of medicinal plants in the Semiarid Region of Brazil. Brazilian J Biol Sci. 2015;2:51-74.

4. Beltreschi L, Lima RB, Cruz DD. Traditional botanical knowledge of medicinal plants in a "quilombola" community in the Atlantic Forest of northeastern Brazil. Environ Dev Sustain. 2018. https://doi.org/10.1007/ s10668-017-0079-6.

5. Thomas E, Semo L, Morales M, Noza Z, Nuñez H, Cayuba A, et al. Ethnomedicinal practices and medicinal plant knowledge of the Yuracarés and Trinitarios from Indigenous Territory and National Park Isiboro-Sécure. Bolivian Amazon J Ethnopharmacol. 2011;133:153-63.

6. Miara MD, Teixidor-Toneu I, Sahnoun T, Bendif H, Ait HM. Herbal remedies and traditional knowledge of the Tuareg community in the region of Illizi (Algerian Sahara). J Arid Environ. 2019;167:65-73.

7. Amri E, Kisangau DP. Ethnomedicinal study of plants used in villages around Kimboza forest reserve in Morogoro. Tanzania J Ethnobiol Ethnomed. 2012;8:1 
8. Tounekti T, Mahdhi M, Khemira H. Ethnobotanical study of indigenous medicinal plants of Jazan region, Saudi Arabia. Evidence-based Complement Altern Med. 2019;2019.

9. Santos ABN, Araújo MP, Sousa RS, Lemos JR, Santos ABN, Araújo MP, et al. Plantas medicinais conhecidas na zona urbana de Cajueiro da Praia, Piauí, Nordeste do Brasil. Rev Bras Plantas Med. 2016;18:442-50.

10. Monteiro JM, Ramos MA, Araújo EL, Amorim ELC, Albuquerque UP. Dynamics of medicinal plants knowledge and commerce in an urban ecosystem (Pernambuco, Northeast Brazil). Env Monit Assess. 2011;178:179-202.

11. Lima PGC, Coelho-Ferreira M, Oliveira R. A floresta na feira: plantas medicinais do município de Itaituba, Pará, Brasil. Fragm Cult. 2014;24:285-301.

12. Alves CAB, Silva S, Belarmino NALA, Souza RS, Silva DR, Alves PRR, et al. Comercialização de plantas medicinais: um estudo etnobotânico na feira livre do município de Guarabira, Paraíba, Nordeste do Brasil. Gaia Sci. 2016;10:390-407.

13. Mati $\mathrm{E}, \mathrm{Boer} \mathrm{H}$. Ethnobotany and trade of medicinal plants in the Qaysari Market, Kurdish Autonomous Region. Iraq J Ethnopharmacol. 2011;133:490-510.

14. Tinitana F, Rios M, Romero-Benavides JC, De La Cruz RM, Pardo-DeSantayana M. Medicinal plants sold at traditional markets in southern Ecuador. J Ethnobiol Ethnomed. 2016;12:1-18.

15. Delbanco A-S, Burgess ND, Cuni-Sanchez A. Medicinal Plant Trade in Northern Kenya: economic importance, uses, and origin. Econ Bot. 2017;71:13-31.

16. Medeiros PM, Haydée Ladio A, Albuquerque UP. Patterns of medicinal plant use by inhabitants of Brazilian urban and rural areas: a macroscale investigation based on available literature. J Ethnopharmacol. 2013:150:729-46.

17. Napagoda MT, Sundarapperuma T, Fonseka D, Amarasiri S, Gunaratna P. Traditional uses of medicinal plants in Polonnaruwa District in North Central Province of Sri Lanka. Scientifica. 2019;2019.

18. Albuquerque UP, Monteiro JM, Ramos MA, Amorim ELC. Medicinal and magic plants from a public market in northeastern Brazil. J Ethnopharmacol. 2007:110:76-91.

19. Brandão MGL, Cosenza GP, Pereira FL, Vasconcelos AS, Fagg CW. Changes in the trade in native medicinal plants in Brazilian public markets. Environ Monit Assess. 2013.

20. Lima PGC, Coelho-Ferreira M, Oliveira R. Plantas medicinais em feiras e mercados públicos do Distrito Florestal Sustentável da BR-163, estado do Pará. Brasil Acta Bot Bras. 2011;25:422-34.

21. Bussmann RW, Paniagua Zambrana NY, Moya Huanca LA, Hart R. Changing markets - Medicinal plants in the markets of La Paz and El Alto, Bolivia. J Ethnopharmacol. 2016;193:76-95.

22. Bussmann RW, Sharon D, Vandebroek I, Jones A, Revene Z. Health for sale: the medicinal plant markets in Trujillo and Chiclayo, Northern Peru. J Ethnobiol Ethnomed. 2007:3:37

23. Almeida CFCBR, Albuquerque UP. Uso e conservação de plantas e animais medicinais no estado de pernambuco (nordeste do brasil): Um estudo de caso. Interciencia. 2002;27:276-285.

24. Anselmo AF, Silva CG, Marinho M das GV, Zanella FCV, Xavier DA. Levantamento Etnobotânico de Plantas Medicinais Comercializadas por raizeiros em uma Feira Livre no Município de Patos-PB. Biofar. 2012;Especial:39-48.

25. Albuquerque UP, Medeiros PM, Almeida ALS, Monteiro JM, Lins Neto EMF, Melo JG, et al. Medicinal plants of the caatinga (semi-arid) vegetation of NE Brazil: a quantitative approach. J Ethnopharmacol. 2007;114:325-54.

26. Hilonga S, Otieno JN, Ghorbani A, Pereus D, Kocyan A, de Boer H. Trade of wild-harvested medicinal plant species in local markets of Tanzania and its implications for conservation. South African J Bot. 2019;122:214-24.

27. Nankaya J, Nampushi J, Petenya S, Balslev H. Ethnomedicinal plants of the Loita Maasai of Kenya. Environ Dev Sustain. 2019;1-21.

28. Catarino S, Duarte MC, Costa E, Carrero PG, Romeiras MM. Conservation and sustainable use of the medicinal Leguminosae plants from Angola. PeerJ. 2019;7:e6736.

29. Maioli-Azevedo V, Fonseca-Kruel VS. Plantas medicinais e ritualísticas vendidas em feiras livres no Município do Rio de Janeiro, RJ, Brasil: estudo de caso nas zonas Norte e Sul RJ, Brazil: a case study in the North and South zones. Acta Bot Brasilica. 2007;21:263-75.

30. Lima PGC, Coelho-Ferreira M, da Silva SR. Perspectives on medicinal plants in public markets across the Amazon: a review. Econ Bot. 2016:70:64-78.
31. Pala NA Sarkar BC, Shukla G, Chettri N, Deb S, Bhat JA, et al. Floristic composition and utilization of ethnomedicinal plant species in home gardens of the Eastern Himalaya. J Ethnobiol Ethnomed. 2019;15.

32. Panyadee $P$, Balslev $H$, Wangpakapattanawong P, Inta A. Medicinal plants in homegardens of four ethnic groups in Thailand. J Ethnopharmacol. 2019;239.

33. Kunwar RM, Mahat L, Acharya RP, Bussmann RW. Medicinal plants, traditional medicine, markets and management in far-west Nepal. J Ethnobiol Ethnomed. 2013:9.

34. Semotiuk AJ, Semotiuk NL, Ezcurra E. The Eruption of Technology in Traditional Medicine: How Social Media Guides the Sale of Natural Plant Products in the Sonoran Desert Region. Econ Bot. 2015;69:360-9.

35. IBGE. IBGE :: Instituto Brasileiro de Geografia e Estatística. 2017 [cited 2018 Sep 13]. https://ww2.ibge.gov.br/home/geociencias/geografia/default_ div_int.shtm

36. Moreira ERF. Mesorregiões e microrregiões da Paraiba : delimitação e caracterização. João Pessoa: GAPLAN; 1988.

37. Francisco PRM, Medeiros RM, Santos D, Matos RM. Classificação Climática de Köppen e Thornthwaite para o Estado da Paraíba Paulo. Rev Bras Geogr Física. 2015;8:1006-16.

38. REFLORA. Flora do Brasil 2020. [cited 2018 Sep 3]. http://floradobrasil.jbrj. gov.br/reflora/listaBrasil/PrincipalUC/PrincipalUC.do\#CondicaoTaxonCP

39. Tropicos. [cited 2018 Sep 3]. http://www.tropicos.org/

40. ICD. ICD-10 Version: 2010 [Internet]. 2010 [cited 2018 Sep 26]. http://apps. who.int/classifications/icd10/browse/2010/en

41. Bennett BC, Prance GT. Introduced Plants in the Indigenous Pharmacopoeia of Northern South America. Econ Bot. 2000;54:90-102.

42. Guedes RS, Zanella FCV, Costa Júnior JEV, Santana GM, Silva JA. Caracterização florístico-fitossociológica do componente lenhoso de um trecho de Caatinga no semiárido paraibano. Rev Caatinga. 2012;25:99-108.

43. Sabino FGS, Cunha M do CL, Santana GM. Estrutura da vegetação em dois fragmentos de Caatinga antropizada na Paraíba. Floresta e Ambient. 2016;23:487-497.

44. Dickel ML, Rates SMK, Ritter MR. Plants popularly used for losing weight purposes in Porto Alegre, South Brazil. J Ethnopharmacol. 2007:109:60-71.

45. Arenas PM, Molares S, Aguilar Contreras A, Doumecq B, Gabrielli F. Ethnobotanical, micrographic and pharmacological features of plant-based weight-loss products sold in naturist stores in Mexico City: The need for better quality control. Acta Bot Bras. 2013;27:560-79.

46. Molares S, Arenas PM, Aguilar A. Etnobotánica urbana de los productos vegetales adelgazantes comercializados en México DF. Bol Latinoam y de Caribe Plantas Med y Aromat. 2012;11:400-12.

47. Yaseen G, Ahmad M, Sultana S, Suleiman Alharrasi A, Hussain J, Zafar $M$, et al. Ethnobotany of medicinal plants in the Thar Desert (Sindh) of Pakistan. J Ethnopharmacol. 2015;163:43-59.

48. Gomes TB, Bandeira FPS de F. Uso e diversidade de plantas medicinais em uma comunidade quilombola no Raso da Catarina, Bahia. Acta Bot Bras. 2012;26:796-809.

49. Bolson M, Hefler SR, Dall'Oglio Chaves El, Gasparotto Junior A, Cardozo Junior EL. Ethno-medicinal study of plants used for treatment of human ailments, with residents of the surrounding region of forest fragments of Paraná, Brazil. J Ethnopharmacol. 2015:161:1-10.

50. Albuquerque UP, Oliveira RF. Is the use-impact on native caatinga species in Brazil reduced by the high species richness of medicinal plants? J Ethnopharmacol. 2007;113:156-70.

51. Agra MF, Baracho GS, Nurit K, Basílio IJLD, Coelho VPM. Medicinal and poisonous diversity of the flora of "Cariri Paraibano", Brazil. J Ethnopharmacol. 2007;111:383-95.

52. Cunha MCL, Silva Júnior MC. Flora e Estrutura de Floresta Estacional Semidecidual Montana nos Estados da Paraíba e Pernambuco. Nativa Revista Nativa. 2014;2:95-102.

53. Silva AJR, Andrade LHC. Cultural significance of plants in communities located in the Coastal Forest Zone of the State of Pernambuco, Brazil. Hum Ecol. 2006;34:447-65.

54. Crepaldi MOS, Peixoto AL. Use and knowledge of plants by"Quilombolas" as subsidies for conservation efforts in an area of Atlantic Forest in Espírito Santo State, Brazil. Biodivers Conserv. 2010;19:37-60.

55. Conde BE, Ticktin T, Fonseca AS, Macedo AL, Orsi TO, Chedier LM, et al. Local ecological knowledge and its relationship with biodiversity 
conservation among two Quilombola groups living in the Atlantic Rainforest, Brazil. PLoS ONE. 2017;12:e0187599.

56. Leonti M. The future is written: Impact of scripts on the cognition, selection, knowledge and transmission of medicinal plant use and its implications for ethnobotany and ethnopharmacology. J Ethnopharmacol. 2011;134:542-55.

\section{Publisher's Note}

Springer Nature remains neutral with regard to jurisdictional claims in published maps and institutional affiliations.

- fast, convenient online submission

- thorough peer review by experienced researchers in your field

- rapid publication on acceptance

- support for research data, including large and complex data types

- gold Open Access which fosters wider collaboration and increased citations

- maximum visibility for your research: over $100 \mathrm{M}$ website views per year

At BMC, research is always in progress.

Learn more biomedcentral.com/submissions 